\title{
The use of novel electrospun scaffolds in musculoskeletal tissue engineering: a focus on the rotator cuff
}

Dr Navraj S Nagra* ${ }^{1,2}$, Dr Edward T Stace* ${ }^{1}$, Saket Tibrewal ${ }^{3}$, Wasim Khan ${ }^{4}$, Prof Andrew J Carr $^{1}$

${ }^{1}$ Nufiield Department of Orthopaedics Rheumatology and Musculoskeletal Sciences (NDORMS), University of Oxford, Botnar Research Centre, Nuffield Orthopaedic Centre, Headington, Oxford

${ }^{2}$ Oxford University Clinical Academic Graduate School (OUCAGS), Medical Sciences Divisional Office, Level 3, John Radcliffe Hospital, Oxford

${ }^{3}$ Nuffield Orthopaedic Centre, Oxford University Hospitals NHS Foundation Trust, Headington, Oxford

${ }^{4}$ Division of Trauma and Orthopaedic Surgery, University of Cambridge, Addenbrooke's Hospital, Cambridge

${ }^{*}$ Co-first authors 


\section{Introduction}

The ageing worldwide population has put degenerative pathologies under the spotlight for scientists and clinicians. This is particularly true of musculoskeletal disease, where rising treatment expenses, ADL disruption and lost workdays (8.8 million workdays are lost annually in the UK) are a significant and growing burden to global economies.

Within musculoskeletal disease, ligament and tendon pathology remain incompletely understood and inadequately treated. Rotator Cuff (RC) tears affect 15\% of 60 years olds, increasing to $30 \%$ of 80 years olds ${ }^{61}$. Even after optimal non-operative management, many patients progress to surgery. In 2015, there were 400,000 such surgical repairs in the USA and 10,000 in the UK, representing a $700 \%$ increase over the preceeding decade. However, recent data from the UKUFF trial indicates that surgical procedures fail in $40 \%$ of patients within 12 months regardless of technique (unpublished data), with other studies reporting failure rates as high as $94 \%{ }^{16}$.

Current repairs involve suturing damaged tendon back to bone and often attempting to augment the repair with an artificial or biological scaffold. These scaffolds are designed to provide mechanical support but do not actively help regenerate the underlying tendon. Conversely they may produce inflammation, foreign body reactions and fistula formation, ultimately increasing failure rates. Scaffolds are predominantly decellularised matrix from animal xenografts and human cadaveric allografts; but synthetic polymer products are also used. Commercially available patches are relatively homogenous in structure, shape and surface morphology, not reflecting the complex transition zone from tendon to bone tissue, or the nanoscale topographic features of tendon known to influence resident tenocyte behaviour.

The growing market pressure and current limitations in RC repair strategies have spurred interest in a Tissue Engineering/Regenerative Medicine solution to assist in soft tissue repair.

\section{'Tissue Engineering/Regenerative Medicine' (TERM)}

TERM strategies consist of one or more components of the tissue engineering triad (Figure 1):

\section{Bioactive molecules and/or growth factors.}

The importance of these molecules stems from the greater understanding of their role in tendon development and potential role in influencing differentiation of pluripotent cells 
towards a tenocytic lineage. One such factor, Fibroblast Growth Factor (FGF) induces Tendon Progenitor Cells (TNPs) within the embryo through the action of Scleraxis $(\mathrm{Scx})^{52}$, a transcription factor gene specific to differentiation towards TNPs ${ }^{47,64}$. FGF has been shown to mediate repair in rotator cuff tears ${ }^{11}$ by stimulating cell proliferation and migration in addition to fibroblastic collagen production, and angiogenesis at injury sites $^{11,58,62}$. Moreover, in vitro studies have also shown potential for FGF and Growth Differentiation Factor (GDF) factors in increasing the speed and strength of tendon healing $^{12,25,60}$. These factors may have a supplementary role in tendon repair.

Transforming Growth Factor $\beta$ (TGF $\beta$ ), is another molecule which has been shown to be integral in expression of Scx and subsequent genesis of tendons in the embryo. Pryce et al. found that Tgfb2(-/-) and Tgfb3(-/-) double mutant murine embryos did not develop tendons or ligaments in the limbs, trunk, tail and head ${ }^{47}$. Further evidence within canine models has shown that combinations of Insulin-like Growth Factor (IGF1) and $\mathrm{TGF} \beta 1^{51}$ and that $\mathrm{TGF} \beta 3^{27}$ within a $3 \mathrm{D}$ structure, can aid in differentiation of MSCs towards a tenogenic lineage.

\section{Cells}

Cell populations utilised for TERM can be categorised into stem cell (predominantly MSCs and increasingly iPSCs) and differentiated cell populations.

MSCs are stem cells capable of differentiating into connective tissue phenotypes such as bone, cartilage, tendon, muscle and fat. They are found in bone marrow or adipose tissue and offer a plentiful source for tissue engineering. There is a paucity of evidence that MSCs alone can regenerate tissues and contrarily, work by Gulotta et al. in murine models has shown that adding unaltered MSCs to healing RC entheses has no effect in collagen fibre organisation or the mechanical properties of repaired tendon ${ }^{17}$. However, work from the same group has shown that by manipulating MSCs with viral vectors for certain genes such as MT1-MMP ${ }^{18}$ (upregulated during embryogenesis at the tendon bone enthesis) and $\mathrm{Scx}^{19}$, RC repairs have higher load and stress to failure values in addition to higher stiffness with increased fibrocartilage volume on histology. In the context of scaffolds, Yokoya et al. have shown that MSCs in the presence of a PGA 
sheet, can improve the strength of repair compared to a scaffold or traditional repair alone $^{72}$.

No up-to-date review would be complete without acknowledging the recent paradigm shift reframing MSCs as more than sources of terminally differentiated cells, but rather trophic and/or immunomodulatory cells, regenerating host cells ${ }^{55}$. Work in this field, in the musculoskeletal context has yet to be explored. Moreover, tendon progenitor cells have recently been isolated with characteristics of "clonogenicity, multipotency and self-renewal", although research is still in its infancy, these cells have the potential to act as a source of tenocytes.

Native cells have been investigated as tissue engineering treatments (autologous tenocyte implantation) and randomised controlled trials are currently underway to determine efficacy ${ }^{22}$. Case reports have shown positive results ${ }^{66}$. Barriers to such therapies include the limited availability of donor sites, donor site morbidity, reduced replication rates and functionality of aged cells and potentially lengthy in vitro culture expansion times with associated phenotypic drift $^{70}$.

\section{Scaffolds}

Physical frameworks, either biologic and synthetic, are important in providing structural integrity and mechanical properties to tissues immediately after repair, ideally matching those of the tissue they are implanted in. Scaffolds can also contribute an intricate 3D environment for cells at a nano scale. This is important for tendon regeneration as mature tendon has a highly organised hierarchical structure down to the collagen fibrils (100-200nm). Scaffolds can provide nano scale biophysical cues to promote cell differentiation and matrix production ${ }^{20}$. Furthermore, scaffold matrix chemistry influences cell adhesion to the matrix ${ }^{49}$ and migration into it ${ }^{53}$.

\section{Electrospinning}

Electrospinning is an attractive technique for tendon TERM biomaterial production as it allows fabrication of fibres similar in size and alignment to those occurring in natural extracellular 
matrix $^{46,57}$. Electrospun scaffolds can also be easily modified to manipulate the scaffold mechanical, biological and physical properties, potentially explaining the significant increase in electrospinning in MSK research over the past decade (Figure 2)

Basic electrospinning (figure 3A) involves injecting a solution into an electric field. The electric field stretches the solution towards a collector. When the electrostatic force overcomes the surface tension of the solution, the solution erupts towards the collector (Figure 3B). Whilst travelling to the collector, the volatile solvent evaporates leaving solid fibres distributed on the collector.

\section{Electrospinning advancements}

\section{Pre-fabrication}

Solvents and salts can added to change the viscosity and dielectric constant of the solution and consequently the behaviour during electrospinning ${ }^{24,59,65}$. Molecules can also be combined through direct blending so they are incorporated into the fibres during electrospinning. Drugs to influence cell response ${ }^{68,75}$, nanomaterials to alter mechanical properties ${ }^{54}$ (He 2014, Kolluru 2014) as well as DNA plasmids and siRNAs to manipulate gene expression have been successfully combined ${ }^{9,37}$.

\section{During fabrication}

During the electrospinning process, modifications of electrospinning variables can alter the size, alignment and density of the fibres. It is also possible to spin from multiple spinnerets to combine fibres of different materials or sizes. Additionally, cells have been included in the electrospinning process, transforming a scaffold from an inductive or conductive scaffold to an independently autogenic tissue ${ }^{63}$.

\section{Post-fabrication}

After electrospinning, fibres can be cross-linked ${ }^{5}$ and annealed ${ }^{33}$ to alter mechanical properties or undergo other surface treatments such as salt leaching ${ }^{41}$ to further modify the surface morphology and biological activity of the materials.

\section{Modified Electrospinning Techniques}


A number of advanced electrospinning techniques have been developed to further enhance electrospinning's capabilities. Melt Electrospinning uses molten polymers to allow electrospinning of semi-crystalline polymers not suitable for traditional solvent based spinning. Emulsion electrospinning allows inclusion of proteins and hydrophilic molecules not amenable to direct blending in organic solvents. Low Temperature Electrospinning results in ice crystals forming between fibres which on melting leaves an increased distance between fibres. Co-axial spinning feeds two solutions into the electric field through a modified spinneret to allow generation of fibres with different surface and core materials. 


\section{Materials and Methods}

\section{Search strategy and criteria (Figure 5)}

A study protocol was developed and a literature search of the MEDLINE/PubMed database was conducted between December 2015 and January 2016 using the search string 'electrospinning AND tendon'.

Exclusion criteria applied to studies were: publication date greater than five years, non-English language publications, review articles and non-musculoskeletal cell-type studies. Studies satisfying inclusion and exclusion criteria were independently reviewed by two of the authors (NSN and ETS).

\section{Outcomes of search}

Of 38 initial studies, eighteen were included in the systematic review (Table 1). All studies were basic science in nature, with seven (38.9\%) reporting animal in vivo work and none with human clinical data.

Varying outcome measures were reported and common themes identified. These included (1) using electrospinning technology for drug delivery, (2) use of novel and biological materials in manufacture of scaffold, (3) increased mechanical strengths of materials, and (4) techniques to improve the nanotopographical properties of scaffolds. 


\section{Results}

\section{Drug Delivery}

The incorporation of drugs into scaffolds and the drug release profiles were the predominant outcome measure of several studies ${ }^{26,34,36,76}$. Techniques employed to incorporate the molecules into electrospun scaffolds were varied and included dissolving drugs directly into the electrospinning solution ( $\mathrm{bFGF}^{74}$, naproxen ${ }^{36}$ and hyaluronan) or producing an emulsion with hydrosols (mitomycin C [MMC]). One study made use of bFGF-loaded nanoparticles for drug release ${ }^{34}$.

Lui et al. used PLLA and PCL dissolved in HFIP to produce different scaffolds with a constant proportion of naproxen. They found that increasing the proportion of PLLA:PCL in the electrospun substrate was negatively correlated to percentage release of naproxen; moreover, by using water as a co-solvent to HFIP, sustained drug release up to three weeks was achieved. Seeded murine cells lines indicated that naproxen had no effect on cell viability or morphology.

Zhao et al. incorporated bFGF incorporated into scaffolds, noting a burst release of $15.4 \%$ over the first 48 hours with subsequent release for a further 22 days. They also demonstrated human dermal fibroblasts seeded onto such scaffolds proliferated faster and maintained phenotype more than cells seeded on non-bioactive control scaffolds.

Further work by Liu et al. compared bFGF incorporated in dextran glassy nanoparticles to bFGF included directly in the electrospinning process. They found that nanoparticles facilitated a steady release pattern with no burst release, of greater duration (30 vs 20 days) and with a higher cumulative release of drug (6400pg vs 2900pg) than non-nanoparticle controls. Both studies using bFGF demonstrated decreased adhesion formation and improved collagen organisation and mechanical properties in murine models.

In scaffolds with MMC included as hydrosols, a burst with $26-31 \%$ of the drug was seen in the first 48 hours with a subsequent tailoring off after the next six days. MMC concentration was indirectly related to cell viability, proliferation and a tenocytic phenotype. In rat Achilles and rabbit FDP models, MMC hydrosol scaffolds reduced inflammation and peritendinous adhesions with the improved fibre orientation ${ }^{75}$.

Liu et al. incorporated hyaluronic acid (HA) into PCL scaffolds. Gradual release patterns were observed after initial bursts, especially at 4 and $8 \%$ HA. By increasing the proportion of HA, 
the tensile strength of the scaffolds fell (from 2.13 to $1.55 \mathrm{MPa}$ as HA percentage increased from 0 to $12 \%$ ). Conversely the tensile moduli increased as the HA percentage increased. In vitro models demonstrated that pluripotent murine stem cells attached to PCL/HA scaffolds and proliferated more as HA percentage composition increased. A galline tendon-healing model demonstrated that at $12 \% \mathrm{HA} / \mathrm{PCL}$, scaffolds reduced the severity of peritendinous adhesions and increased tendon healing scores compared to PCL only scaffolds ${ }^{35}$.

\section{Clinical applications}

Novel methods to aid in vivo studies have been proposed. Martin et al. described a method by which scaffolds could be studied post-implantation through radiographic imaging; they introduced zirconium(IV) oxide nanoparticles molecules into electrospun solution, with good biocompatibility found in vivo murine intervertebral disc and ex vivo bovine meniscal tear models $^{39}$. Specifically, they found good overlying fibrous but not calcific deposition. However, in vitro studies found that metabolic activity of bovine MSCs seeded on the scaffolds was lower than that of TCP. Importantly, microCT was used to visualise the implants, which has directly transferable benefits for patients, where healing can be monitored, migration and impingement can be detected and scaffolds can be localised should any revision be required.

\section{Biodegradable materials}

Cellulose, gelatin, hyaluronan, chitosan, silk and digested animal tendon tissue used as components in the production of scaffolds over the review period. Zhang et al. found that a combination of chitosan and gelatin produced scaffolds via a Stable Jet Electrospinning (SJES) technique, were of a more linear morphology and, increased tensile and greater elasticity than controls produced by conventional electrospinning techniques ${ }^{73}$. The SJES scaffolds had a tenogenic influence on human iPSCs with in vitro models demonstrating a fibroblastic phenotype, tenogenic gene expression, and non-osteogenic phenotype with no variation in cell proliferation rates compared to controls. An in vivo murine Achilles tendon model, with human iPSCs seeded into the tendon, showed SJES scaffolds increased the spindle morphology of cells, number of collagen fibres and collagen fibre size (27.8\% larger than controls). Similar to in vitro work, IHC showed increased tenogenic and decreased osteogenic gene expression. Furthermore, mechanical properties (increased stiffness, failure force, stress at failure and Young's modulus) were improved in the SJES group.

Chainani et al. used mechanical and chemical techniques to digest porcine tendon pulverised tendon tissue into a powder and coated this onto a PCL electrospun scaffold ${ }^{10}$. Increased yield strength was found after 28 days of culture with human ASCs, in addition to indications of cells 
division, matrix deposition (increased collagen 1), and tenogenic gene expression, more so than controls without tendon coating.

Silk fibroin was integrated into scaffolds in two different manners. Yang et al. made use of dissolving degummed silk into chemical solvent and blending this to form an electrospinning substrate $^{69}$; whereas Naghashzargar et al. electrospun conventional materials (e.g. PCL) onto silk fibroin yarns ${ }^{40}$. Silk substrate scaffolds and silk fibroin electrospinning techniques, which were seeded with murine BMMSCs and murine fibroblasts respectively, showed no change in cytocompatibility and improved mechanical properties.

\section{Mechanical Properties}

The common themes to augment electrospun scaffold mechanical properties were the formation of nanoyarn scaffolds and the addition of nanoparticles.

Yang et al. tested three electrospun silk and PCL scaffolds; (1) aligned nanofibrous scaffolds, (2) random nanofibrous scaffolds and (3) Nanoyarn Re-Inforced Scaffolds (NRS) ${ }^{69}$. The Young's modulus, tensile strength and elongation at break were evaluated both parallel and perpendicular to the direction of fibre alignment and at 90 degrees for the randomly orientated scaffold. For the aligned scaffold this equated to Young's moduli values of $433.56 \mathrm{MPa}$ (parallel) and $29.72 \mathrm{MPa}$ (perpendicular) and for the NRS $288.95 \mathrm{MPa}$ and $32.51 \mathrm{MPa}$. No difference was noted for the randomly aligned scaffold. The NRS and aligned scaffolds also had significantly greater tensile strengths in the parallel compared to perpendicular direction. Conversely the elongation at break values were significantly less in the parallel than perpendicular directions, $58.78 \%$ (parallel) and $212 \%$ (perpendicular) for the aligned scaffold and $40.82 \%$ and $162.76 \%$ for the NRS.

$\mathrm{Xu}$ et al. performed similar assessments of their nanoyarn scaffold compared to aligned and random scaffolds ${ }^{67}$. They did not specify if this was done parallel or perpendicular to fibre orientation. They do however note the nanoyarn scaffold had a significantly lower tensile strength and elastic modulus but higher elongation at break value.

He et al. used CNCs at $20 \% \mathrm{w} / \mathrm{v}$ to increase the tensile strength of the CNC-incorporated electrospun scaffolds from $16.6 \mathrm{MPa}$ to $33.6 \mathrm{MPa}$ and the elastic modulus from $0.69 \mathrm{GPa}$ to $1.87 \mathrm{GPa}^{21}$. Cell testing showed no toxic effects from the use of CNCs and cell attachment and spreading patterns consistent with healthy primary human dental follicle cells 
Sheikh et al. added MWCNTS at 0.06, 0.33 and $0.66 \% \mathrm{w} / \mathrm{v}$ to increase the tensile stress of scaffolds from $11.4 \mathrm{MPa}$ without MWCNTS to $39.6 \mathrm{MPa}, 51.23 \mathrm{MPa}$ and $32.99 \mathrm{MPa}$ respectively ${ }^{54}$. Of note, at $0.66 \%$, the MWCNTs were improperly distributed preventing uniform stress distribution and likely resulting in the observed inferior tensile strength. In vitro testing found no negative effects of MWCNT addition on cell behaviour or attachment.

\section{Surface architecture}

A number of studies examined altered surface topography as a means to enhance tendon repair. A common strategy was to increase porosity and thus the ability of cells to infiltrate throughout the scaffold, as well as facilitate nutrient and waste exchange.

Yang et al. increased porosity through the formation of nanoyarns. The NRS had yarns with diameters of $30.56 \mathrm{um}$, comprised of nanofibres with a mean diameter of $868.94 \mathrm{~nm}$ Their NRS had a significantly greater pore size (551.41um) compared to their aligned (16.7um) and random nanofibrous scaffold (72.8um) controls ${ }^{69}$. The porosity of the NRS was higher at $79.2 \%$ compared to $75.1 \%$ and $73.6 \%$ for the random and aligned scaffolds. This increased porosity allowed improved murine MSCs cell infiltration in in vitro testing. MSCs reached 150um into the scaffold by day 7, 300um by day 14 and 500um by day 28 compared to 40um at day 28 on randomly aligned scaffolds and no cell infiltration on aligned scaffolds after 28 days.

$\mathrm{Xu}$ et al. manufactured nanoyarn scaffolds with a mean pore size of $28.5 \mathrm{um}$ compared to aligned (4.43um) and randomly aligned (4.31um) scaffolds ${ }^{67}$. The porosities were reported as $85.9 \%$ for the nanoyarn scaffold compared to $73.9 \%$ and $74.1 \%$ for the random and aligned scaffolds respectively. Primary rabbit tenocytes seeded on to the nanoyarn scaffold were able to better infiltrate the scaffold over 14 days of culture compared to cells seeded onto aligned and random nanofibre controls. This finding was supported by significantly higher cell counts on their nanoyarn scaffold at 7 and 14 days culture compared to controls. rtPCR showed primary tenocytes seeded on the nanoyarn scaffold expressed significantly higher levels of collagen 1 , collagen 3, Decorin, Tenascin C and Biglycan mRNA compared to cells seeded on random and aligned nanofibrous scaffolds.

Beason et al. fabricated PCL scaffolds of increasing porosity using a sacrificial fibre technique. This involved co-spinning a PCL-PEO scaffold ${ }^{6}$. When submerged in ethanol, the soluble PEO dissolves leaving solely PCL fibre scaffolds. The vacant space left by PEO fibres increases the porosity compared to the controls spun using PCL alone (Baker et al. 2008 ${ }^{4}$ ). The high and low porosity scaffolds were then tested in a murine rotator cuff model. At 4 and 8 weeks in vivo, 
cell infiltration and colonization were lower in the sacrificial high porosity PEO/PCL scaffold compared to the less porous PCL scaffold.

On the nanoscale, fibre alignment can be manipulated to alter tenocyte behaviour. Orr et al.tested multi-layered aligned nanofibre scaffolds against multi-layered random nanofibre scaffolds ${ }^{44}$. The mean fibre diameter of aligned and non-aligned scaffolds was not significantly different at $1.76 \mathrm{um}$ and $1.57 \mathrm{um}$ respectively. The fiber alignment index of aligned scaffolds was 17 times greater than that for non-aligned scaffolds. Both scaffolds supported hASC growth with cells invading through the full thickness of the scaffolds. However collagen deposition was more abundant in aligned scaffolds when assessed by Picrosirius red staining. Furthermore COL3A1 and TNMD mRNA expression was higher on aligned scaffolds. After 28 days of culture, aligned scaffolds demonstrated greater increases in Young's modulus and yield stress than those observed in non-aligned scaffolds.

Samavedi et al. fabricated scaffolds of altering alignment to engineer a scaffold more suitable for replicating the complex transition between bone and tendon for use in patella tendon reconstruction ${ }^{50}$. Using three different spinnerets and shields, a three-zoned scaffold was fabricated to increase biomimicry of the native bone-tendon-bone junction for patella tendon repair. A 3 part scaffold was fabricated with random PLGA fibres (mimicking bone) transitioning to aligned PCL fibres (mimicking tendon), with the PCL fibres again transitioning back to the random PLGAfibres. The PLGA sections had a tensile modulus of 24-28MPa, three times that of the PCL sections, better replicating the nanoenvironment of bone. Culture of MSCs on the scaffold showed aligned cells with high aspect rations on the aligned PCL component (similar to tenocytes) and polygonal randomly orientated cells on the unaligned PGLA section (similar to osteoblasts). 


\section{Discussion}

This review of literature highlights the current directions under investigation and consideration for tendon TERM research regeneration and can aid researchers.

\section{Drug delivery}

As drugs are developed for more specific molecular targets, there is an increased need to prevent adverse systemic side effects, whilst lengthening the half-life and effect in the targetted pathological tissue. Nanotechnology ${ }^{45}$, liposome ${ }^{3}$ and polymeric micelle $^{29}$ technologies have all been considered for drug delivery, though none of these mechanisms would have the initial proximity and potential longevity an electrospun scaffold implanted within target tissue could.

We found five original research papers looking into delivery of naproxen, celecoxib, Mitomycin C (MMC) and growth factors such as bFGF ${ }^{26,36,67,74,76}$. These molecules were investigated secondary to previously published work suggesting potential efficacy in tendinopathy. Although primarily used as an anti-tumour drug, Mitomycin $\mathrm{C}$ (MMC) has been shown to inhibit adhesion formation through upregulation of the apoptotic gene Bax within fibroblasts ${ }^{30}$ in animal tendon repair models. Toxicity and severity of side effects have previously limited the use of the drug within a scaffold, as release profiles were unsafe. Similarly, naproxen (an NSAID) has been shown to prevent adhesion formation and reduce inflammation, leading to it being a commonly prescribed therapy for tendinopathy. Furthermore, celecoxib, a selective COX-2 inhibitor acts to inhibit fibroblast proliferation and collagen expression by inhibiting ERK1/2 and SMAD2/3 phosphorylation of the cells. Finally, having its efficacy through angiogenesis and propagation of an anabolic phenotype, bFGF is a growth factor that has previously in vitro and in vivo been shown to improve tendon repair.

In addition to anti-adhesion and anti-inflammatory molecules, future targets include vascular proliferation after Bjur et al. discovered an association between increased neovascularisation of tendon and pain in tendinopathy ${ }^{1,8}$. Neural pathways in painful tendinopathy were associated with vascular structures within Achilles tendon biopsy samples. This prompted pilot use of polidocanol (a sclerosing agent) injection in patients with painful tendinopathy. The initial study found an $80 \%$ patient satisfaction 
rate and significantly reduced Visual Analogue Score (VAS) for pain (from 74 to 8), and a marked reduction in vascularisation in the Achilles tendons of this group ${ }^{42}$; these findings have been substantiated in a double-blinded RCT of twenty patients ${ }^{2}$, though it should be noted that the benefits were not conferred in a separate RCT for patellar tendinopathy ${ }^{23}$. Polidocanol has been shown to be compatible with incorporation into an electrospun scaffold, though cytocompatibility and mechanical properties have yet to be determined ${ }^{48}$.

\section{Biodegradable materials}

Use of biodegradable materials in electrospinning has increased recently for a number of practical benefits. Although their beneficial properties vary according to source, biodegradable materials can be biocompatible, non-immunogenic/inflammatory (bioinert) and have low toxicity profiles. Some, such as polymers of hyaluronan, have additional bioactive properties such as a conducive role in ECM remodelling; angiogenesis, and influencing wound healing, cell proliferation and motility. When incorporated into, or being the chief constituent of electrospun scaffolds, the biological merits of biodegradable materials are synergised to a larger scale and can be arranged in a manner to influence cell morphology in addition to biological cues.

\section{Mechanical properties}

While electrospun materials may induce favourable cell and tissue behaviour to augment tendon healing, their baseline mechanical properties are often inadequate for tendon repair. As the mechanical environment is crucial for successful tendon repair, techniques to enhance the mechanical properties have advanced over the last decade to harness the favourable biological influences of electrospun fibres into a robust scaffold suitable for surgical implantation. These include altering the polymer material used for electrospinning, combining different fibre types, adding molecules, multi-layered scaffolds, multi-component scaffolds and post fabrication treatments such as annealing and cross-linking - strategies which have seen varying degrees of success.

One prominent strategy over the past 5 years was the use of nanoyarn based scaffolds. The aggregation of fibres into yarns significantly increased the mechanical properties 
of nanoyarn scaffolds above comparable nanofibre scaffolds. Both Yang and $\mathrm{Xu}$ et al. claim to achieve a mechanical strength sufficient for tendon repair through this technique. Another theme to increase mechanical properties was the addition of nanoparticles to the electrospun material, with $\mathrm{He}$ et al. using cellulose nanocrystals (CNCs) in a cellulose electrospun scaffold and Sheikh et al. adding multi-walled carbon nanotubes. These papers suggest that significant augmentation of mechanical properties through nanoparticle addition is achievable without cytotoxicity or compromising cell attachment and behaviour. However, neither of these studies formally assessed gene expression or quantified protein expression in scaffolds with the added nanomaterials. A negative influence on tenocyte behaviour and gene expression could result in inferior clinical outcomes even with adequate cell attachment and proliferation.

\section{Surface architecture}

Originally ECM was thought to provide physical and spatial support for the embedded cell population, with cell behaviour driven largely through molecular clues from nearby or distant cells and cell-cell interaction. However, with the ability to fabricate scaffolds and materials with deliberate variances at the nanoscale, the importance and influence of cell-matrix interactions is becoming more apparent. This interaction is bidirectional, with cells initiating ECM changes and ECM changes altering cell behaviour. This dynamic interaction, termed Biophysical Epigenetic Regulation (BER), is involved from stem cell differentiation ${ }^{14}$ through to carcinogenesis ${ }^{38}$. BER occurs in biological and synthetic nano-topographies ${ }^{13,56}$. Significantly for RCT repair, cell-scaffold interactions have enhanced tenocyte repair mechanisms, matrix deposition and cell phenotype ${ }^{28,77,15,32,31,43,71}$. Harnessing these cues into a tendon repair scaffold could significantly improve rotator cuff repair outcomes.

We have identified a number of studies examining altered surface topography to enhance tendon repair. One strategy was to increase porosity and thus the ability of cells to infiltrate throughout the scaffold, as well as assist in nutrient and waste exchange. Increasing porosity was achieved in a variety of methods including nanoyarn formation (Yang et al., Xu et al.), multilayered scaffolds (Orr et al.) and 
sacrificial co-spun scaffolds where one fibre population was removed by submersion in ethanol prior to experimentation (Beason et al.).

In addition to increasing cell invasion and proliferation, Xu and Yang et al. showed a support of tenocyte phenotype in nanoyarn scaffolds in vitro. Faster cell infiltration, higher cell counts and increased tendon matrix ECM gene expression are suggestive of a scaffold which would facilitate tendon repair.

Beason et al.'s work, however, shows extrapolation from in vitro to in vivo results is complicated. The reduced infiltration observed in vivo on the lower porosity scaffold was the opposite of previous in vitro and subcutaneous in vivo models suggesting the advantage of increased porosity may be negated through poor handling or poor implantation practices or when placed under pressure and strain in vivo in real world situations. Engineering porosity into a scaffold which can handle the challenges of implantation and in vivo function requires further work.

Manipulating the nano-architecture had considerable influence as shown by Orr et al. and Samavedi et al. Increasing fibre alignment promoted collagen deposition, mechanical strength and ECM gene mRNA expression in hASCs. Differing fibre alignment and mechanical properties in PCL and PLGA areas within a single scaffold were able to promote MSC shape changes consistent with differentiation down tendon and bone lineages. Unfortunately no gene expression or further cell characterization data were published to support these achievements. However the cell shape changes suggestive of differentiation down two cell lineages in morphologically distinct scaffold areas are a testament to the increasing complexity and promise of electrospun biomaterial design.

\section{Limitations}

Many studies have used biodegradable materials for obvious reasons. However the in vitro and in vivo models have not assessed the effects of degradation. Degradation will impact on the mechanical properties weakening the scaffold significantly. Exploration of the timeframes over which this occurs is crucial so it can be matched to the rate of tendon tissue deposition and maturation to ensure the mechanical 
strength of the repair is always great enough to prevent breakdown.

In scientific research, extrapolation of in vitro to in vivo results is difficult. The lack of representative in vitro tissue testing and in vivo models in the studies reviewed further complicates this. Specifically in vitro human tissue/cell cytocompatibility testing was conducted in less than $15 \%$ of the fifteen papers. Furthermore in vivo testing was limited to murine and galline models, known to not reflect the larger forces acting in human tissues.

These difficulties were highlighted by Beason et al.'. In vitro data suggested the more porous scaffolds would allow better cell infiltration, ECM deposition and mechanical properties when implanted in a rotator cuff tear model, however the opposite was observed. Consequently many of these scaffolds, whilst showing significant promise in vitro, will need significantly more research and experimentation with human tissue, both in vitro and in vivo, before a new generation of electrospun biomaterials can be incorporated into clinical practice.

With all drug delivery system experiments, cytocompatibility was another metric of success for these drugs, although limited human cell-line testing was performed, and influence of fibroblast phenotype and viability were contradictorily used as a positive and negative marker of success ${ }^{26,36,67,74,76}$.

\section{Conclusion}

The optimal bioengineered scaffold for tendon repair will be of sufficient mechanical strength to support the repair site, degrade at a rate matched to tendon regeneration without causing inflammation, incorporate bioactive molecule and nanotopographic features to promote tendon regeneration. Evidently, a product which can perform in such manner will be challenging to engineer, and as further layers of complexity are added, potential complications and increasing cost would have to be considered.

\section{References}


1. Alfredson $\mathrm{H}$, Cook J. A treatment algorithm for managing Achilles tendinopathy: new treatment options. Br. J. Sports Med. 2007;41(4):211-6. doi:10.1136/bjsm.2007.035543.

2. Alfredson H, Ohberg L. Sclerosing injections to areas of neo-vascularisation reduce pain in chronic Achilles tendinopathy: a double-blind randomised controlled trial. Knee Surg. Sports Traumatol. Arthrosc. 2005;13(4):338-44. doi:10.1007/s00167-004-0585-6.

3. Allen TM, Cullis PR. Liposomal drug delivery systems: from concept to clinical applications. Adv. Drug Deliv. Rev. 2013;65(1):36-48. doi:10.1016/j.addr.2012.09.037.

4. Baker BM, Gee AO, Metter RB, et al. The potential to improve cell infiltration in composite fiber-aligned electrospun scaffolds by the selective removal of sacrificial fibers. Biomaterials 2008;29(15):2348-58.

doi:10.1016/j.biomaterials.2008.01.032.

5. Barnes CP, Pemble CW, Brand DD, Simpson DG, Bowlin GL. Cross-linking electrospun type II collagen tissue engineering scaffolds with carbodiimide in ethanol. Tissue Eng. 2007;13(7):1593-605. doi:10.1089/ten.2006.0292.

6. Beason DP, Connizzo BK, Dourte LM, et al. Fiber-aligned polymer scaffolds for rotator cuff repair in a rat model. J. Shoulder Elbow Surg. 2012;21(2):24550. doi:10.1016/j.jse.2011.10.021.

7. Bi Y, Ehirchiou D, Kilts TM, et al. Identification of tendon stem/progenitor cells and the role of the extracellular matrix in their niche. Nat. Med. 2007;13(10):1219-27. doi:10.1038/nm1630.

8. Bjur D, Alfredson H, Forsgren S. The innervation pattern of the human Achilles tendon: studies of the normal and tendinosis tendon with markers for general and sensory innervation. Cell Tissue Res. 2005;320(1):201-6. doi:10.1007/s00441-004-1014-3.

9. Cao H, Jiang X, Chai C, Chew SY. RNA interference by nanofiber-based siRNA delivery system. J. Control. Release 2010;144(2):203-12. doi:10.1016/j.jconrel.2010.02.003.

10. Chainani A, Hippensteel KJ, Kishan A, et al. Multilayered electrospun scaffolds for tendon tissue engineering. Tissue Eng. Part A 2013;19(2324):2594-604. doi:10.1089/ten.TEA.2013.0165.

11. Chang J, Most D, Thunder R, Mehrara B, Longaker MT, Lineaweaver WC. Molecular studies in flexor tendon wound healing: the role of basic fibroblast growth factor gene expression. J. Hand Surg. Am. 1998;23(6):1052-8. doi:10.1016/S0363-5023(98)80015-4.

12. Dines JS, Weber L, Razzano P, et al. The effect of growth differentiation factor-5-coated sutures on tendon repair in a rat model. J. Shoulder Elbow Surg. 16(5 Suppl):S215-21. doi:10.1016/j.jse.2007.03.001.

13. Downing TL, Soto J, Morez C, et al. Biophysical regulation of epigenetic state and cell reprogramming. Nat. Mater. 2013;12(12):1154-62. doi:10.1038/nmat3777.

14. Engler AJ, Sen S, Sweeney HL, Discher DE. Matrix elasticity directs stem cell lineage specification. Cell 2006;126(4):677-89. doi:10.1016/j.cell.2006.06.044.

15. Erisken C, Zhang X, Moffat KL, Levine WN, Lu HH. Scaffold fiber diameter regulates human tendon fibroblast growth and differentiation. Tissue Eng. Part A 2013;19(3-4):519-28. doi:10.1089/ten.tea.2012.0072.

16. Galatz LM, Ball CM, Teefey SA, Middleton WD, Yamaguchi K. The outcome and repair integrity of completely arthroscopically repaired large and massive 
rotator cuff tears. J. Bone Joint Surg. Am. 2004;86-A(2):219-24. Available at: http://jbjs.org/content/86/2/219.abstract. Accessed September 1, 2015.

17. Gulotta L V, Kovacevic D, Ehteshami JR, Dagher E, Packer JD, Rodeo SA. Application of bone marrow-derived mesenchymal stem cells in a rotator cuff repair model. Am. J. Sports Med. 2009;37(11):2126-33. doi:10.1177/0363546509339582.

18. Gulotta L V, Kovacevic D, Montgomery S, Ehteshami JR, Packer JD, Rodeo SA. Stem cells genetically modified with the developmental gene MT1-MMP improve regeneration of the supraspinatus tendon-to-bone insertion site. Am. J. Sports Med. 2010;38(7):1429-37. doi:10.1177/0363546510361235.

19. Gulotta L V, Kovacevic D, Packer JD, Deng XH, Rodeo SA. Bone marrowderived mesenchymal stem cells transduced with scleraxis improve rotator cuff healing in a rat model. Am. J. Sports Med. 2011;39(6):1282-9. doi:10.1177/0363546510395485.

20. Hakimi O, Mouthuy PA, Zargar N, Lostis E, Morrey M, Carr A. A layered electrospun and woven surgical scaffold to enhance endogenous tendon repair. Acta Biomater. 2015;26:124-135. doi:10.1016/j.actbio.2015.08.007.

21. He X, Xiao Q, Lu C, et al. Uniaxially aligned electrospun all-cellulose nanocomposite nanofibers reinforced with cellulose nanocrystals: scaffold for tissue engineering. Biomacromolecules 2014;15(2):618-27. doi:10.1021/bm401656a.

22. Ho JO, Sawadkar P, Mudera V. A review on the use of cell therapy in the treatment of tendon disease and injuries. J. Tissue Eng. 2014;5:2041731414549678. doi:10.1177/2041731414549678.

23. Hoksrud A, Torgalsen T, Harstad H, et al. Ultrasound-guided sclerosis of neovessels in patellar tendinopathy: a prospective study of 101 patients. Am. J. Sports Med. 2012;40(3):542-7. doi:10.1177/0363546511433012.

24. Huang $\mathrm{C}$, Chen $\mathrm{S}$, Lai C, et al. Electrospun polymer nanofibres with small diameters. Nanotechnology 2006;17(6):1558-63. doi:10.1088/0957$4484 / 17 / 6 / 004$.

25. Ide J, Kikukawa K, Hirose J, et al. The effect of a local application of fibroblast growth factor- 2 on tendon-to-bone remodeling in rats with acute injury and repair of the supraspinatus tendon. J. Shoulder Elbow Surg. 18(3):391-8. doi:10.1016/j.jse.2009.01.013.

26. Jiang S, Yan H, Fan D, Song J, Fan C. Multi-layer electrospun membrane mimicking tendon sheath for prevention of tendon adhesions. Int. J. Mol. Sci. 2015;16(4):6932-44. doi:10.3390/ijms16046932.

27. Kapacee Z, Yeung C-YC, Lu Y, Crabtree D, Holmes DF, Kadler KE. Synthesis of embryonic tendon-like tissue by human marrow stromal/mesenchymal stem cells requires a three-dimensional environment and transforming growth factor 33. Matrix Biol. 2010;29(8):668-77. doi:10.1016/j.matbio.2010.08.005.

28. Kapoor A, Caporali EHG, Kenis PJA, Stewart MC. Microtopographically patterned surfaces promote the alignment of tenocytes and extracellular collagen. Acta Biomater. 2010;6(7):2580-9. doi:10.1016/j.actbio.2009.12.047.

29. Kedar U, Phutane P, Shidhaye S, Kadam V. Advances in polymeric micelles for drug delivery and tumor targeting. Nanomedicine 2010;6(6):714-29. doi:10.1016/j.nano.2010.05.005.

30. Kim T, Choi S, Lee HK, Cho YJ, Kim EK. Mitomycin C induces apoptosis in cultured corneal fibroblasts derived from type II granular corneal dystrophy corneas. 2008. Available at: https://www.molvis.org/molvis/v14/a143/. 
Accessed February 9, 2016.

31. Kishore V, Bullock W, Sun X, Van Dyke WS, Akkus O. Tenogenic differentiation of human MSCs induced by the topography of electrochemically aligned collagen threads. Biomaterials 2012;33(7):2137-44.

doi:10.1016/j.biomaterials.2011.11.066.

32. Lee $\mathrm{CH}$, Shin HJ, Cho IH, et al. Nanofiber alignment and direction of mechanical strain affect the ECM production of human ACL fibroblast. Biomaterials 2005;26(11):1261-70. doi:10.1016/j.biomaterials.2004.04.037.

33. Liu J, Bauer AJP, Li B. Solvent vapor annealing: an efficient approach for inscribing secondary nanostructures onto electrospun fibers. Macromol. Rapid Commun. 2014;35(17):1503-8. doi:10.1002/marc.201400274.

34. Liu S, Qin M, Hu C, et al. Tendon healing and anti-adhesion properties of electrospun fibrous membranes containing bFGF loaded nanoparticles. Biomaterials 2013;34(19):4690-701. doi:10.1016/j.biomaterials.2013.03.026.

35. Liu S, Zhao J, Ruan H, et al. Biomimetic sheath membrane via electrospinning for antiadhesion of repaired tendon. Biomacromolecules 2012;13(11):3611-9. doi:10.1021/bm301022p.

36. Lui YS, Lewis MP, Loo SCJ. Sustained-release of naproxen sodium from electrospun-aligned PLLA-PCL scaffolds. J. Tissue Eng. Regen. Med. 2015. doi:10.1002/term.2000.

37. Luu YK, Kim K, Hsiao BS, Chu B, Hadjiargyrou M. Development of a nanostructured DNA delivery scaffold via electrospinning of PLGA and PLAPEG block copolymers. J. Control. Release 2003;89(2):341-53. Available at: http://www.ncbi.nlm.nih.gov/pubmed/12711456. Accessed February 12, 2016.

38. Maffini M V, Soto AM, Calabro JM, Ucci AA, Sonnenschein C. The stroma as a crucial target in rat mammary gland carcinogenesis. J. Cell Sci. 2004;117(Pt 8):1495-502. doi:10.1242/jcs.01000.

39. Martin JT, Milby AH, Ikuta K, et al. A radiopaque electrospun scaffold for engineering fibrous musculoskeletal tissues: Scaffold characterization and in vivo applications. Acta Biomater. 2015;26:97-104. doi:10.1016/j.actbio.2015.08.001.

40. Naghashzargar E, Farè S, Catto V, et al. Nano/micro hybrid scaffold of PCL or P3HB nanofibers combined with silk fibroin for tendon and ligament tissue engineering. J. Appl. Biomater. Funct. Mater. 13(2):e156-68. doi: $10.5301 / \mathrm{jabfm} .5000216$.

41. Nseir N, Regev O, Kaully T, Blumenthal J, Levenberg S, Zussman E. Biodegradable scaffold fabricated of electrospun albumin fibers: mechanical and biological characterization. Tissue Eng. Part C. Methods 2013;19(4):25764. doi:10.1089/ten.TEC.2012.0118.

42. Ohberg L, Alfredson H. Ultrasound guided sclerosis of neovessels in painful chronic Achilles tendinosis: pilot study of a new treatment. Br. J. Sports Med. 2002;36(3):173-5; discussion 176-7. Available at:

http://www.pubmedcentral.nih.gov/articlerender.fcgi?artid=1724500\&tool=pm centrez\&rendertype=abstract. Accessed December 12, 2015.

43. Omae H, Zhao C, Sun YL, An K-N, Amadio PC. Multilayer tendon slices seeded with bone marrow stromal cells: a novel composite for tendon engineering. J. Orthop. Res. 2009;27(7):937-42. doi:10.1002/jor.20823.

44. Orr SB, Chainani A, Hippensteel KJ, et al. Aligned multilayered electrospun scaffolds for rotator cuff tendon tissue engineering. Acta Biomater. 2015;24:117-26. doi:10.1016/j.actbio.2015.06.010. 
45. Park K. Nanotechnology: What it can do for drug delivery. J. Control. Release 2007;120(1-2):1-3. doi:10.1016/j.jconrel.2007.05.003.

46. Prospects of Tendon Tissue Engineering in Sports Medicine. Available at: http://www.zeitschrift-sportmedizin.de/artikel-online/archiv-2012/heft5/prospects-of-tendon-tissue-engineering-in-sports-medicine/. Accessed February 12, 2016.

47. Pryce BA, Watson SS, Murchison ND, Staverosky JA, Dünker N, Schweitzer R. Recruitment and maintenance of tendon progenitors by TGFbeta signaling are essential for tendon formation. Development 2009;136(8):1351-61. doi:10.1242/dev.027342.

48. Puhl S, Ilko D, Li L, Holzgrabe U, Meinel L, Germershaus O. Protein release from electrospun nonwovens: improving the release characteristics through rational combination of polyester blend matrices with polidocanol. Int. J. Pharm. 2014;477(1-2):273-81. doi:10.1016/j.ijpharm.2014.10.047.

49. Rho KS, Jeong L, Lee G, et al. Electrospinning of collagen nanofibers: effects on the behavior of normal human keratinocytes and early-stage wound healing. Biomaterials 2006;27(8):1452-61. doi:10.1016/j.biomaterials.2005.08.004.

50. Samavedi S, Vaidya P, Gaddam P, Whittington AR, Goldstein AS. Electrospun meshes possessing region-wise differences in fiber orientation, diameter, chemistry and mechanical properties for engineering bone-ligament-bone tissues. Biotechnol. Bioeng. 2014;111(12):2549-59. doi:10.1002/bit.25299.

51. Schneider PRA, Buhrmann C, Mobasheri A, Matis U, Shakibaei M. Threedimensional high-density co-culture with primary tenocytes induces tenogenic differentiation in mesenchymal stem cells. J. Orthop. Res. 2011;29(9):1351-60. doi:10.1002/jor.21400.

52. Schweitzer R, Chyung JH, Murtaugh LC, et al. Analysis of the tendon cell fate using Scleraxis, a specific marker for tendons and ligaments. Development 2001;128(19):3855-66. Available at: http://www.ncbi.nlm.nih.gov/pubmed/11585810. Accessed January 28, 2016.

53. Sell SA, McClure MJ, Barnes CP, et al. Electrospun polydioxanone-elastin blends: potential for bioresorbable vascular grafts. Biomed. Mater. 2006;1(2):72-80. doi:10.1088/1748-6041/1/2/004.

54. Sheikh FA, Macossay J, Cantu T, et al. Imaging, spectroscopy, mechanical, alignment and biocompatibility studies of electrospun medical grade polyurethane (Carbothane??? 3575A) nanofibers and composite nanofibers containing multiwalled carbon nanotubes. J. Mech. Behav. Biomed. Mater. 2015;41:189-198. doi:10.1016/j.jmbbm.2014.10.012.

55. da Silva Meirelles L, Fontes AM, Covas DT, Caplan AI. Mechanisms involved in the therapeutic properties of mesenchymal stem cells. Cytokine Growth Factor Rev. 2009;20(5-6):419-427. doi:10.1016/j.cytogfr.2009.10.002.

56. Spanoudes K, Gaspar D, Pandit A, Zeugolis DI. The biophysical, biochemical, and biological toolbox for tenogenic phenotype maintenance in vitro. Trends Biotechnol. 2014;32(9):474-482.

57. Szentivanyi A, Chakradeo T, Zernetsch H, Glasmacher B. Electrospun cellular microenvironments: Understanding controlled release and scaffold structure. Adv. Drug Deliv. Rev. 2011;63(4-5):209-20. doi:10.1016/j.addr.2010.12.002.

58. Takahashi S, Nakajima M, Kobayashi M, et al. Effect of recombinant basic fibroblast growth factor (bFGF) on fibroblast-like cells from human rotator cuff tendon. Tohoku J. Exp. Med. 2002;198(4):207-14. Available at: http://www.ncbi.nlm.nih.gov/pubmed/12630552. Accessed January 28, 2016. 
59. Tan S-H, Inai R, Kotaki M, Ramakrishna S. Systematic parameter study for ultra-fine fiber fabrication via electrospinning process. Polymer (Guildf). 2005;46(16):6128-6134. doi:10.1016/j.polymer.2005.05.068.

60. Tang JB, Cao Y, Zhu B, Xin K-Q, Wang XT, Liu PY. Adeno-associated virus2-mediated bFGF gene transfer to digital flexor tendons significantly increases healing strength. an in vivo study. J. Bone Joint Surg. Am. 2008;90(5):1078-89. doi:10.2106/JBJS.F.01188.

61. Thangarajah T, Pendegrass CJ, Shahbazi S, Lambert S, Alexander S, Blunn GW. Augmentation of Rotator Cuff Repair With Soft Tissue Scaffolds. Orthop. J. Sport. Med. 2015;3(6):2325967115587495. doi:10.1177/2325967115587495.

62. Thomopoulos S, Harwood FL, Silva MJ, Amiel D, Gelberman RH. Effect of several growth factors on canine flexor tendon fibroblast proliferation and collagen synthesis in vitro. J. Hand Surg. Am. 2005;30(3):441-7. doi:10.1016/j.jhsa.2004.12.006.

63. Townsend-Nicholson A, Jayasinghe SN. Cell electrospinning: a unique biotechnique for encapsulating living organisms for generating active biological microthreads/scaffolds. Biomacromolecules 2006;7(12):3364-9. doi:10.1021/bm060649h.

64. Tozer S, Duprez D. Tendon and ligament: development, repair and disease. Birth Defects Res. C. Embryo Today 2005;75(3):226-36. doi:10.1002/bdrc.20049.

65. Tungprapa S, Puangparn T, Weerasombut M, et al. Electrospun cellulose acetate fibers: effect of solvent system on morphology and fiber diameter. Cellulose 2007;14(6):563-575. doi:10.1007/s10570-007-9113-4.

66. Wang AW, Bauer S, Goonatillake M, Breidahl W, Zheng M-H. Autologous tenocyte implantation, a novel treatment for partial-thickness rotator cuff tear and tendinopathy in an elite athlete. BMJ Case Rep. 2013;2013(jan11_1):bcr2012007899-. doi:10.1136/bcr-2012-007899.

67. Xu Y, Wu J, Wang H, et al. Fabrication of electrospun poly(L-lactide-co-ecaprolactone)/collagen nanoyarn network as a novel, three-dimensional, macroporous, aligned scaffold for tendon tissue engineering. Tissue Eng. Part C. Methods 2013;19(12):925-36. doi:10.1089/ten.TEC.2012.0328.

68. Y.S. L, M.P. L, S.C.J. L. Sustained-release of naproxen sodium fromelectrospun-aligned PLLA- PCL scaffolds. J. Tissue Eng. Regen. Med. 2015. doi:10.1002/term.

69. Yang C, Deng G, Chen W, Ye X, Mo X. A novel electrospun-aligned nanoyarn-reinforced nanofibrous scaffold for tendon tissue engineering. Colloids Surf. B. Biointerfaces 2014;122:270-6. doi:10.1016/j.colsurfb.2014.06.061.

70. Yao L, Bestwick CS, Bestwick LA, Maffulli N, Aspden RM. Phenotypic drift in human tenocyte culture. Tissue Eng. 2006;12(7):1843-9. doi:10.1089/ten.2006.12.1843.

71. Yin Z, Chen X, Chen JL, et al. The regulation of tendon stem cell differentiation by the alignment of nanofibers. Biomaterials 2010;31(8):216375. doi:10.1016/j.biomaterials.2009.11.083.

72. Yokoya S, Mochizuki Y, Natsu K, Omae H, Nagata Y, Ochi M. Rotator cuff regeneration using a bioabsorbable material with bone marrow-derived mesenchymal stem cells in a rabbit model. Am. J. Sports Med. 2012;40(6):1259-68. doi:10.1177/0363546512442343. 
73. Zhang C, Yuan H, Liu H, et al. Well-aligned chitosan-based ultrafine fibers committed teno-lineage differentiation of human induced pluripotent stem cells for Achilles tendon regeneration. Biomaterials 2015;53:716-30.

doi:10.1016/j.biomaterials.2015.02.051.

74. Zhao S, Xie X, Pan G, Shen P, Zhao J, Cui W. Healing improvement after rotator cuff repair using gelatin-grafted poly(L-lactide) electrospun fibrous membranes. J. Surg. Res. 2015;193(1):33-42. doi:10.1016/j.jss.2014.08.019.

75. Zhao X, Jiang S, Liu S, et al. Optimization of intrinsic and extrinsic tendon healing through controllable water-soluble mitomycin-C release from electrospun fibers by mediating adhesion-related gene expression. Biomaterials 2015;61:61-74. doi:10.1016/j.biomaterials.2015.05.012.

76. Zhao X, Jiang S, Liu S, et al. Optimization of intrinsic and extrinsic tendon healing through controllable water-soluble mitomycin-C release from electrospun fibers by mediating adhesion-related gene expression. Biomaterials 2015;61:61-74. doi:10.1016/j.biomaterials.2015.05.012.

77. Zhu J, Li J, Wang B, et al. The regulation of phenotype of cultured tenocytes by microgrooved surface structure. Biomaterials 2010;31(27):6952-6958. doi:10.1016/j.biomaterials.2010.05.058. 
Figure 1 TERM with a focus on the musculoskeletal niche. This Venn diagram shows a selection of the range of joints currently being treated with varying elements and combinations of elements of TERM. These treatments range from the bench (IVD) via clinical trials (MSCPRPOAK) to the bedside (ACI).

Acronyms: intervertebral disc (IVD), type 1 collagen (T1Col), hyaluronan (HA), Transforming Growth FactorB1 (TGFB ${ }_{1}$ ), bovine nucleus pulposus/annulus fibrosis (bNP/AF), Bone Morphogenetic Protein (BMP), Platelet-Rich Plasma (PRP), osteoarthritis (OA), Mesenchymal Stem Cells Enhanced With PRP Versus PRP In OA Knee (MSCPRPOAK).

\section{Cells}

Autologous

Chondrocyte

Implantation

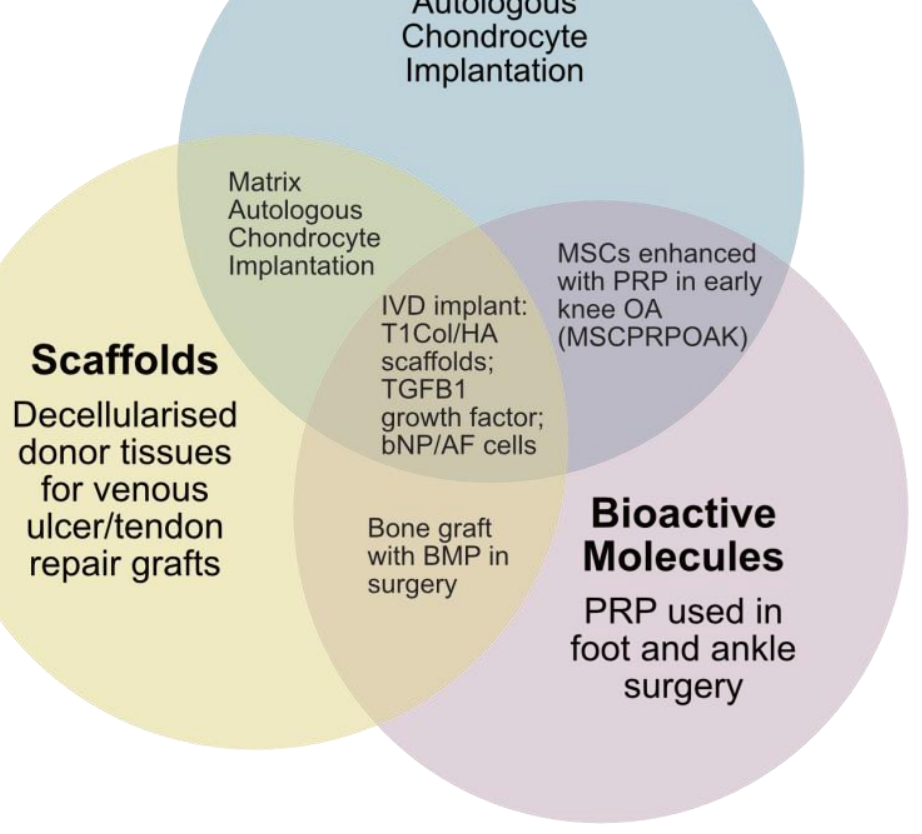


Figure 2 Google Scholar results for articles and patents published for various musculoskeletal tissues and electrospinning over the last 15 years.

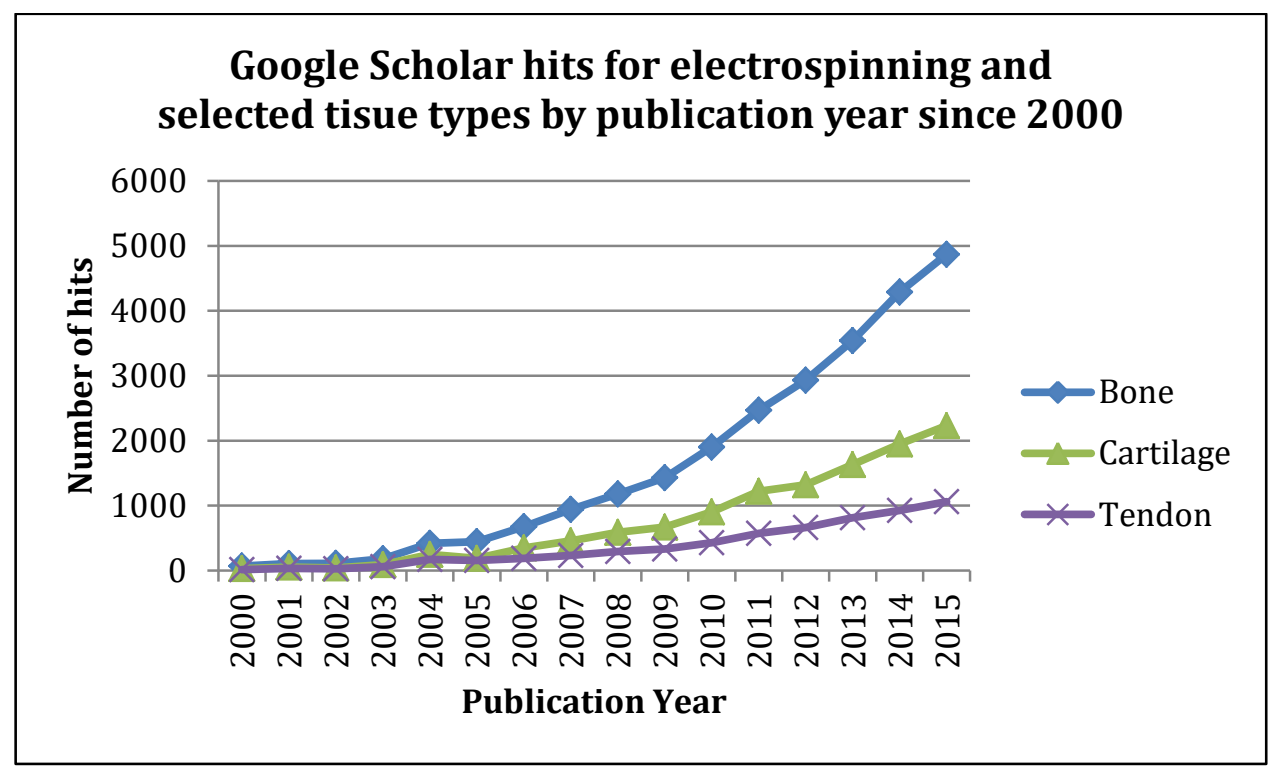


Figure 3 A schematic of a basic electrospinning circuit.

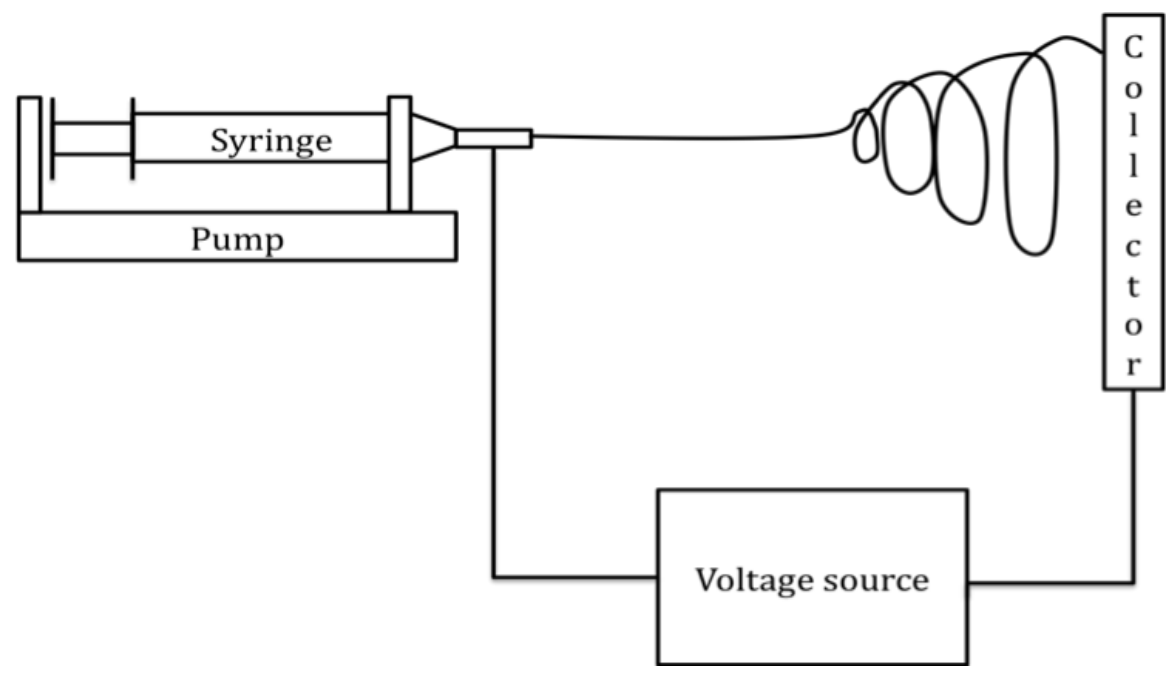


Figure 4 Diagrammatic representation of force balance occurring at the spinneret. With an increasing electrostatic force (moving from panel A-C), surface tension is overcome pulling solutions towards the collector. When these forces are balanced appropriately (C), a Taylor cone is formed and stable, continuous electrospinning is possible.

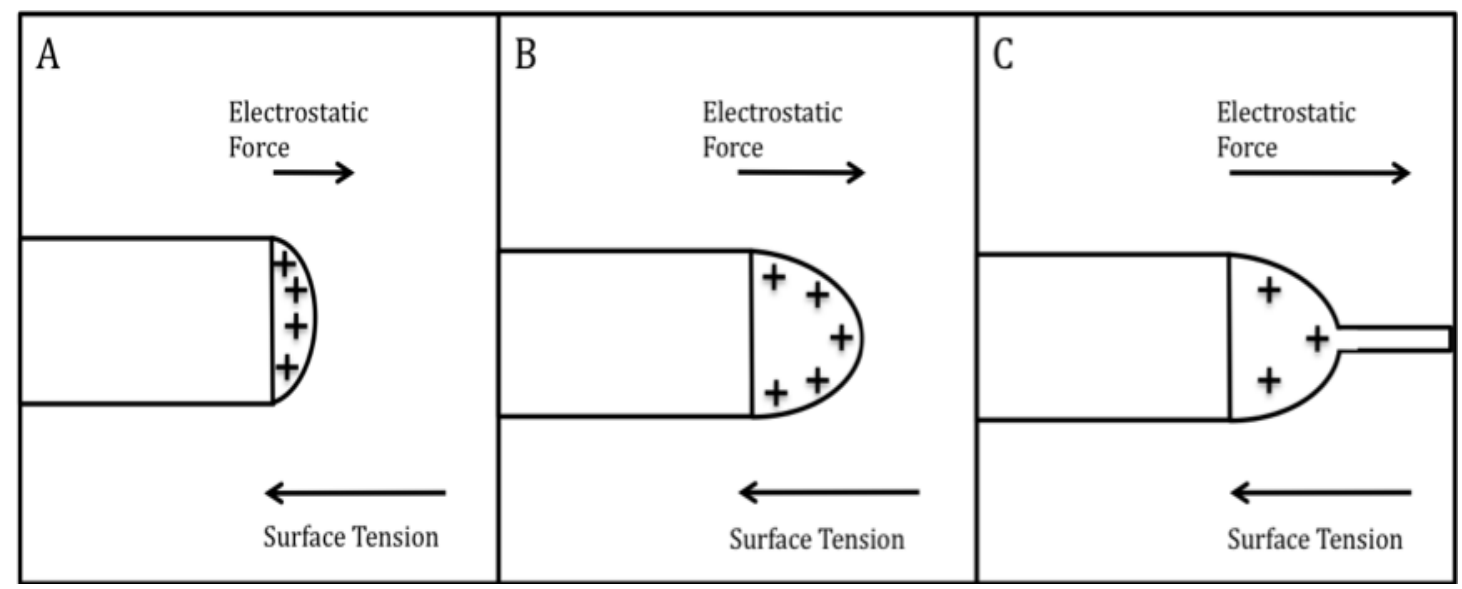


Figure 5 A summary of the search procedure to determine relevant papers. The MEDLINE/PubMed database was searched for papers published over the past five years. The paper referred to with an asterisk (*), by Hakimi et al. is discussed separately.

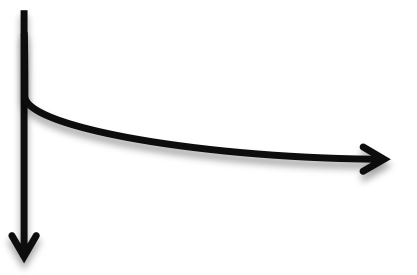

\section{2 papers excluded:}

4 review papers

3 paper with no novel element

3 papers with focus on cell differentiation

1 paper using woven component*

1 paper focussing on cardiomyocytes 


\begin{tabular}{|c|c|c|c|c|}
\hline $\begin{array}{l}\text { Author and } \\
\text { date }\end{array}$ & $\begin{array}{l}\text { Novel } \\
\text { element }\end{array}$ & Materials used & $\begin{array}{l}\text { Supplementar } \\
\text { y details }\end{array}$ & Outcomes \\
\hline $\begin{array}{l}\text { Martin JT et } \\
\text { al. (2015) }\end{array}$ & Radio-opacity & $\begin{array}{l}\text { PCL and radiodense } \\
\text { zirconium (IV) oxide } \\
\text { nanoparticles in THF } \\
\text { and DMF }\end{array}$ & $\begin{array}{l}\text { Standard } \\
\text { electrospinnin } \\
\text { g technique }\end{array}$ & $\begin{array}{l}\text { Cytocompatibility } \\
\text { (with bovine } \\
\text { BMMSCs): Lower } \\
\text { metabolic activity } \\
\text { on scaffold vs TCP. } \\
\text { Animal models: } \\
\text { Bovine meniscal } \\
\text { tear ex vivo model } \\
\text { and murine IVD } \\
\text { replacement in } \\
\text { vivo model: } \\
\text { scaffolds visualised } \\
\text { by fluoroscopy and } \\
\text { MCT. } \\
\text { Tensile modulus: } \\
\text { Increased up to a } \\
25 \% \text { zirconium } \\
\text { Kossa staining } \\
\text { used to exclude } \\
\text { calcium deposition } \\
\text { on radiopaque } \\
\text { scaffolds } \\
\text { Histology showed } \\
\text { biocompatibility } \\
\text { and overlying } \\
\text { fibrous deposition. } \\
\text { Unwanted } \\
\text { osteogenic } \\
\text { potential: Von }\end{array}$ \\
\hline
\end{tabular}




\begin{tabular}{|c|c|c|c|c|}
\hline & & & & concentration. \\
\hline $\begin{array}{l}\text { Orr SB et al. } \\
(2015)\end{array}$ & $\begin{array}{l}\text { Multilayered } \\
\text { scaffold }\end{array}$ & $\begin{array}{l}\mathrm{PCL} \text { dissolved at } \\
100 \mathrm{mg} / \mathrm{mL} \text { in } \mathrm{DCM} \\
\text { and ethanol }\end{array}$ & $\begin{array}{l}\text { Procedure } \\
\text { detail: Needle } \\
\text { fitted with a } \\
\text { 'round wire } \\
\text { mesh focusing } \\
\text { cage' of } 3 \mathrm{~cm} \\
\text { diameter and } \\
\text { a } 13.5 \mathrm{~cm} \\
\text { needle-to- } \\
\text { ground } \\
\text { distance. A } \\
\text { glass slide was } \\
\text { used to collect } \\
\text { sequential } \\
\text { layers of } \\
\text { material, a } \\
\text { total of } 140 \\
\text { times. }\end{array}$ & $\begin{array}{l}\text { Clinically relevant } \\
\text { size of scaffold } \\
\text { (75mm by } \\
\text { 100mm); } 140 \\
\text { layers of material } \\
\text { (1mm thick). } \\
\text { Cytocompatibility } \\
\text { (with human } \\
\text { ASCs): Achieved } \\
\text { complete } \\
\text { infiltration } \\
\text { through scaffold. } \\
\text { Increased } \\
\text { tenogenic gene } \\
\text { expression (TNMD } \\
\text { and COL3A1). } \\
\text { Increased collagen } \\
\text { deposition: Type I } \\
\text { and III collagen. } \\
\text { Increased yield } \\
\text { stress and tensile } \\
\text { modulus at day } 28 \\
\text { vs } 0 .\end{array}$ \\
\hline $\begin{array}{l}\text { Zhao X et al. } \\
\text { (2015) }\end{array}$ & $\begin{array}{l}\text { Drug delivery } \\
\text { (of } \mathrm{MMC} \text { ) }\end{array}$ & $\begin{array}{l}\text { Solvent mixture } \\
\text { of DCM and Span- } 80 \\
\text { (PLLA) was mixed } \\
\text { with MMC/HA } \\
\text { hydrosols, to form } \\
\text { emulsion. DMF and } \\
\text { PLLA were dissolved } \\
\text { in the emulsion. }\end{array}$ & $\begin{array}{l}\text { Standard } \\
\text { electrospinnin } \\
\text { g technique }\end{array}$ & $\begin{array}{l}\text { Cytocompatibility } \\
\text { (with NIH/3T3 } \\
\text { fibroblasts): } \\
\text { Determined } \\
\text { viability (as [MMC] } \\
\text { increases, viability } \\
\text { decreases), } \\
\text { proliferation } \\
\text { (PLLA-MMC }\end{array}$ \\
\hline
\end{tabular}




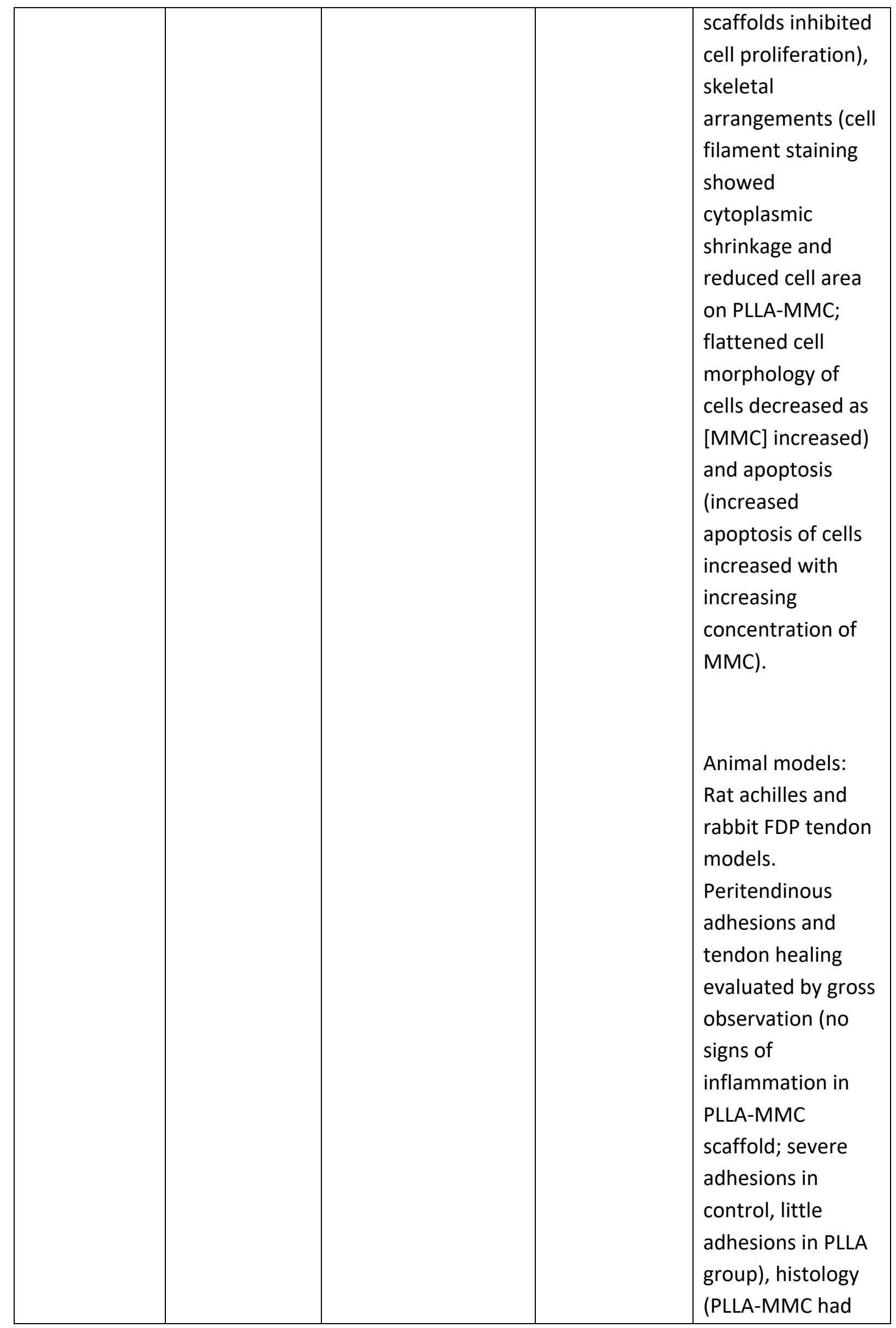




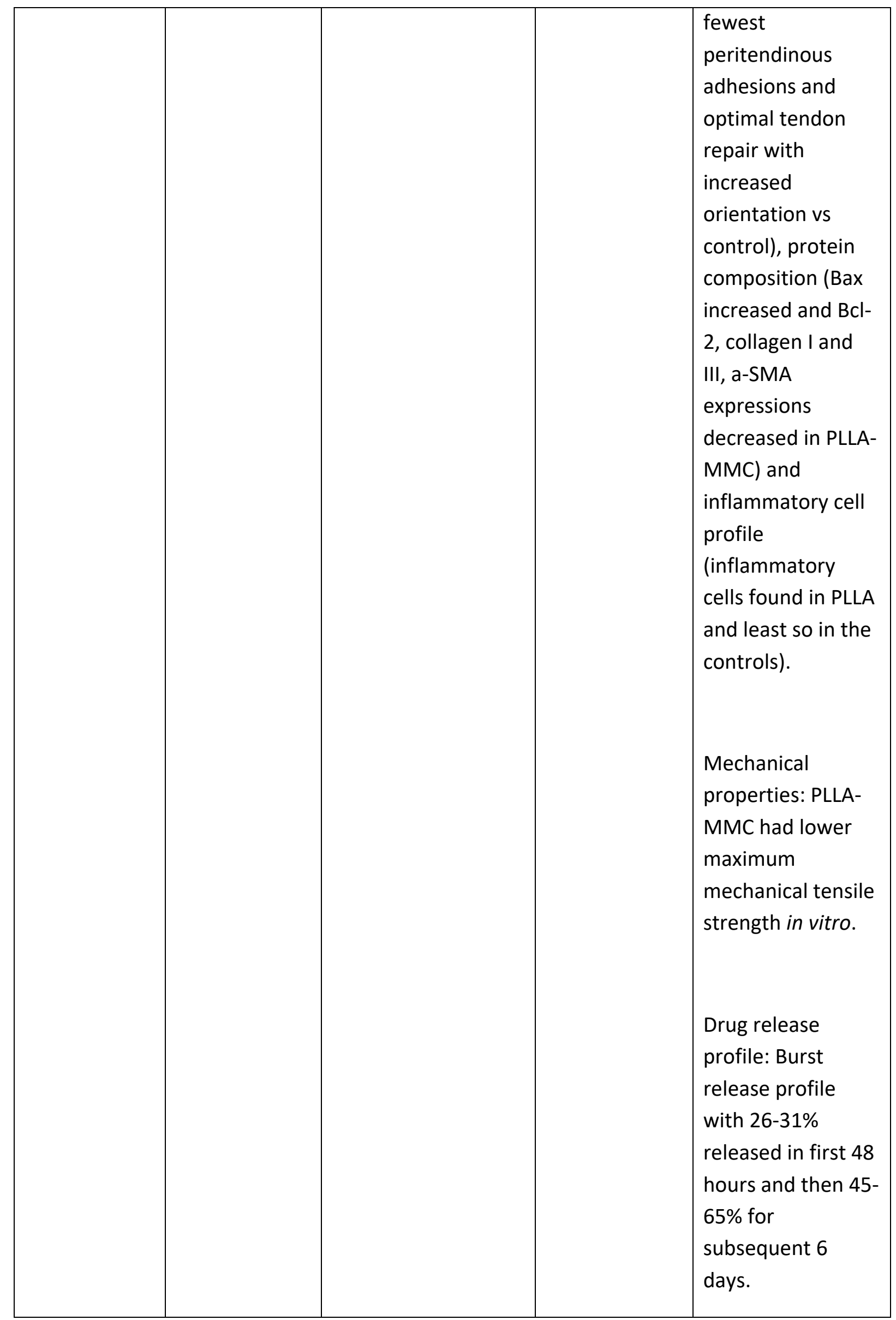




\begin{tabular}{|c|c|c|c|c|}
\hline $\begin{array}{l}\text { Zhang C et al. } \\
\text { (2015) }\end{array}$ & $\begin{array}{l}\text { Stable jet } \\
\text { electrospinnin } \\
g \text { (SJES) - } \\
\text { ultrafine } \\
\text { fibres with } \\
\text { novel } \\
\text { materials } \\
\text { (chitosan) }\end{array}$ & $\begin{array}{l}\text { Two solutions of (1) } \\
\text { Chitosan and gelatin } \\
\text { in trifluoroacetic } \\
\text { acid and (2) PLLA } \\
\text { and PEO in } \\
\text { dichloromethane - } \\
\text { were mixed for the } \\
\text { SJES substrate. }\end{array}$ & $\begin{array}{l}\text { Standard } \\
\text { electrospinnin } \\
\text { g technique } \\
\text { NB. Fibres } \\
\text { were formed } \\
\text { by the } \\
\text { substrate } \\
\text { being } \\
\text { collected on a } \\
\text { high-speed } \\
\text { rotating drum. }\end{array}$ & $\begin{array}{l}\text { SJES produced } \\
\text { scaffolds had } \\
\text { improved fibre } \\
\text { alignment. } \\
\text { Cell differentiation } \\
\text { (human iPSCs): } \\
\text { Assessed by } \\
\text { morphology } \\
\text { (displayed } \\
\text { fibroblastic } \\
\text { phenotype vs } \\
\text { stellate pattern in } \\
\text { controls); gene } \\
\text { expression } \\
\text { (increased SCX, } \\
\text { TNC, MKX, } \\
\text { HoxA11, Tnmd, } \\
\text { Epha4, Col1a1, } \\
\text { Bgn, Fmod, } \\
\text { Col14a1 and Dcn } \\
\text { expression vs } \\
\text { controls); non- } \\
\text { osteogenic } \\
\text { phenotype; and } \\
\text { cell proliferation } \\
\text { (no difference in } \\
\text { cell proliferation } \\
\text { vs control) } \\
\text { modulus four } \\
\text { higher and Young's } \\
\text { Tensile properties: } \\
\text { strength six times } \\
\text { intro tensile } \\
\text { tims }\end{array}$ \\
\hline
\end{tabular}




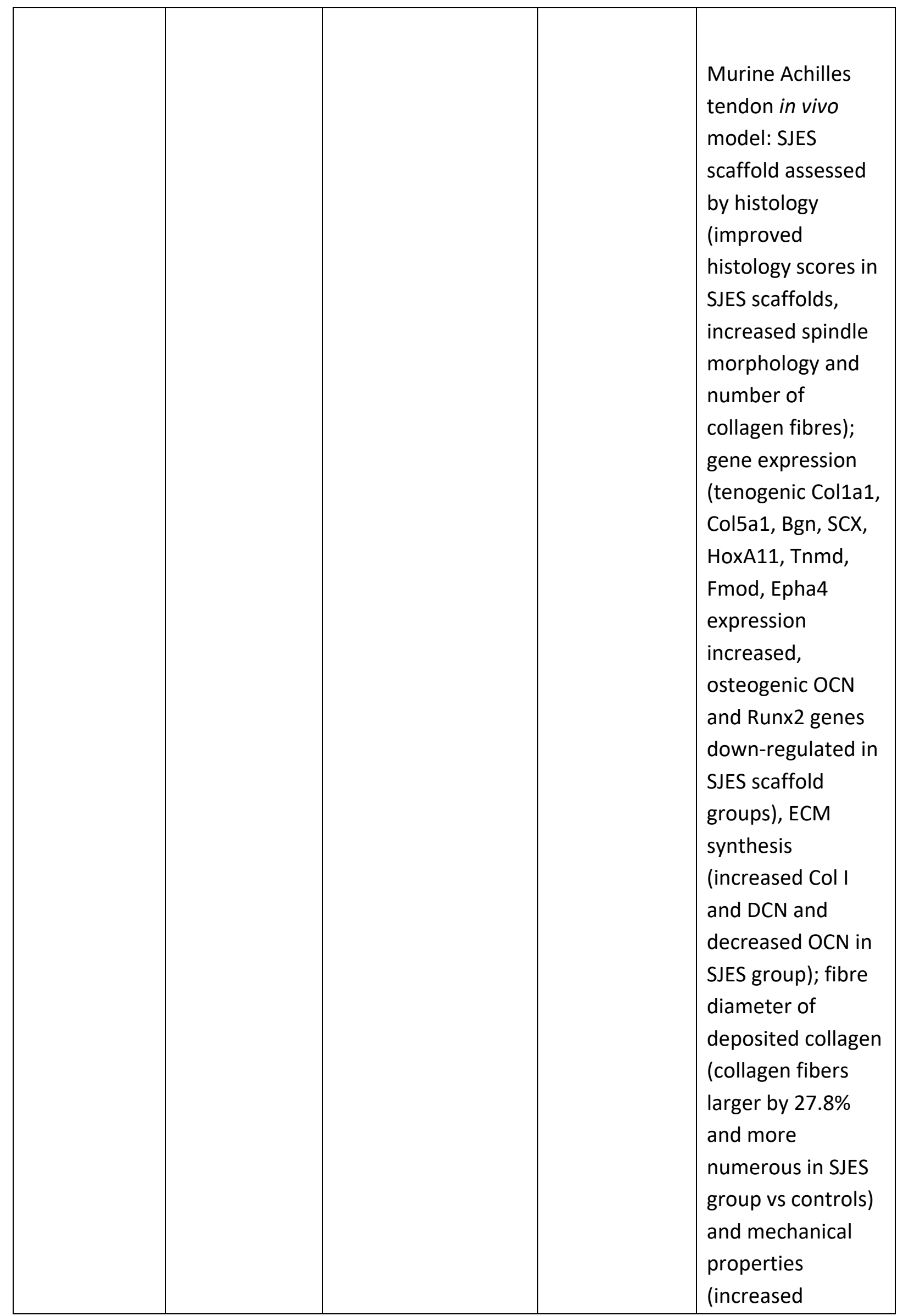




\begin{tabular}{|c|c|c|c|c|}
\hline & & & & $\begin{array}{l}\text { stiffness, failure } \\
\text { force, stress at } \\
\text { failure and Young's } \\
\text { modulus in SJES } \\
\text { group vs controls). }\end{array}$ \\
\hline $\begin{array}{l}\text { Lui YS et al. } \\
\text { (2015) }\end{array}$ & $\begin{array}{l}\text { Drug delivery } \\
\text { (NPS) }\end{array}$ & $\begin{array}{l}\text { NPS was dissolved } \\
\text { with blends of PLLA- } \\
\text { PCL (stated as 90-10, } \\
\text { 80-20). } \\
\text { Scaffolds were } \\
\text { referred to PLLA- } \\
\text { PCL-Water\%. }\end{array}$ & $\begin{array}{l}\text { Standard } \\
\text { electrospinnin } \\
\text { g technique. } \\
\text { NB. Fibres } \\
\text { were collected } \\
\text { on a collector } \\
\text { rotating at } \\
1500 \text { rpm for } \\
\text { aligned fibre } \\
\text { morphology. }\end{array}$ & $\begin{array}{l}\text { Beadless } \\
\text { morphology } \\
\text { achieved. } \\
\text { Drug release } \\
\text { profile: Increasing } \\
\text { PLLA:PCL ratio had } \\
\text { negative effect on } \\
\text { speed of NPS } \\
\text { release (average } \\
66 \% \text { release in first } \\
\text { hour at } 70: 30 \text { ratio } \\
\text { vs } 24 \% \text { in } 90: 10) \text {. } \\
\text { Adding water as } \\
\text { co-solvent to HFIP } \\
\text { produced } \\
\text { sustained release } \\
\text { of up to } 3 \text { weeks. } \\
\text { PLLA:PCL ratio. } 90- \\
10-3 \text { scaffold had }\end{array}$ \\
\hline
\end{tabular}




\begin{tabular}{|c|c|c|c|c|}
\hline & & & & $\begin{array}{l}\text { greatest strain at } \\
\text { break. } \\
\text { Cytocompatibility } \\
\text { (murine } \\
\text { fibroblasts): } \\
\text { viability (no effect) } \\
\text { and morphology } \\
\text { (cells were more } \\
\text { aligned along } \\
\text { scaffold } \\
\text { orientation vs } \\
\text { controls). }\end{array}$ \\
\hline $\begin{array}{l}\text { Sheikh FA et } \\
\text { al. (2015) }\end{array}$ & $\begin{array}{l}\text { Carbothane }^{\mathrm{TM}} \\
\text { 3575A } \\
\text { nanofibers } \\
\text { containing } \\
\text { MWCNTs. }\end{array}$ & $\begin{array}{l}\text { Polyurethane } \\
\text { (Carbothane }{ }^{\text {Tm }} 3575 \mathrm{~A} \\
\text { ): produced by } \\
\text { dissolving polymer } \\
\text { pellets in THF and } \\
\text { DMF. } \\
\text { For nanotubes: } \\
\text { MWCNTs in DMF } \\
\text { added to } \\
\text { polyurethane } \\
\text { solutions to produce } \\
\text { varying MWCNT } \\
\text { concentrations } \\
\text { (0.06\%, } 0.33 \% \text { and } \\
0.66 \% \text { ). }\end{array}$ & $\begin{array}{l}\text { Standard } \\
\text { electrospinnin } \\
\text { g technique. } \\
\text { NB. Rotation } \\
\text { speeds of the } \\
\text { collector } \\
\text { varied from } \\
798-5740 \text { rpm } \\
\text { to produce } \\
\text { varying } \\
\text { morphologies. }\end{array}$ & $\begin{array}{l}\text { Defect and bead } \\
\text { free morphology } \\
\text { of produced } \\
\text { scaffolds and no } \\
\text { change in } \\
\text { nanofibrous } \\
\text { morphology by } \\
\text { addition of } \\
\text { MWCNTs. } \\
\text { Fibre diameter } \\
\text { decreased relative } \\
\text { to increasing } \\
\text { [MWCNT]. } \\
\text { MWCNTs } \\
\text { increased porosity } \\
\text { of nanofibres. } \\
\text { Increased collector } \\
\text { speed produced } \\
\text { greater alignment } \\
\text { in nanofiber } \\
\text { structure. }\end{array}$ \\
\hline
\end{tabular}




\begin{tabular}{|c|c|c|c|c|}
\hline & & & & $\begin{array}{l}\text { Cytocompatibility } \\
\text { (with NIH/3T3 } \\
\text { fibroblasts): } \\
\text { viability and } \\
\text { proliferation } \\
\text { (exponential } \\
\text { growth observed, } \\
\text { scaffolds were } \\
\text { non-toxic). } \\
\text { Mechanical } \\
\text { properties: } \\
\text { MWCNTs in } \\
\text { nanofibers } \\
\text { increased tensile } \\
\text { stress and } \\
\text { complete } \\
\text { alignment of } \\
\text { nanofibers } \\
\text { resulted in } \\
\text { enhanced tensile } \\
\text { stress. }\end{array}$ \\
\hline $\begin{array}{l}\text { Zhao S et al. } \\
\text { (2015) }\end{array}$ & $\begin{array}{l}\text { Biodegradable } \\
\text { gelatin- } \\
\text { grafted PLLA } \\
\text { fibrous } \\
\text { membranes }\end{array}$ & $\begin{array}{l}\text { bFGF and } \\
\text { cyclodextrin in PBS } \\
\text { were dissolved in a } \\
\text { PLGA/chloroform } \\
\text { solution. This } \\
\text { solution was } \\
\text { fabricated for } \\
\text { electrospinning. }\end{array}$ & $\begin{array}{l}\text { Standard } \\
\text { electrospinnin } \\
\text { g technique }\end{array}$ & $\begin{array}{l}\text { A randomly } \\
\text { interconnected } \\
\text { and beadless } \\
\text { fibrous structure, } \\
\text { with uniform fibre } \\
\text { size was produced. } \\
\text { In vitro scaffold } \\
\text { characterisation: } \\
\text { Determined by } \\
\text { mechanical } \\
\text { properties (tensile } \\
\text { strength of PLGA } \\
\text { and bFGF-PLGA }\end{array}$ \\
\hline
\end{tabular}




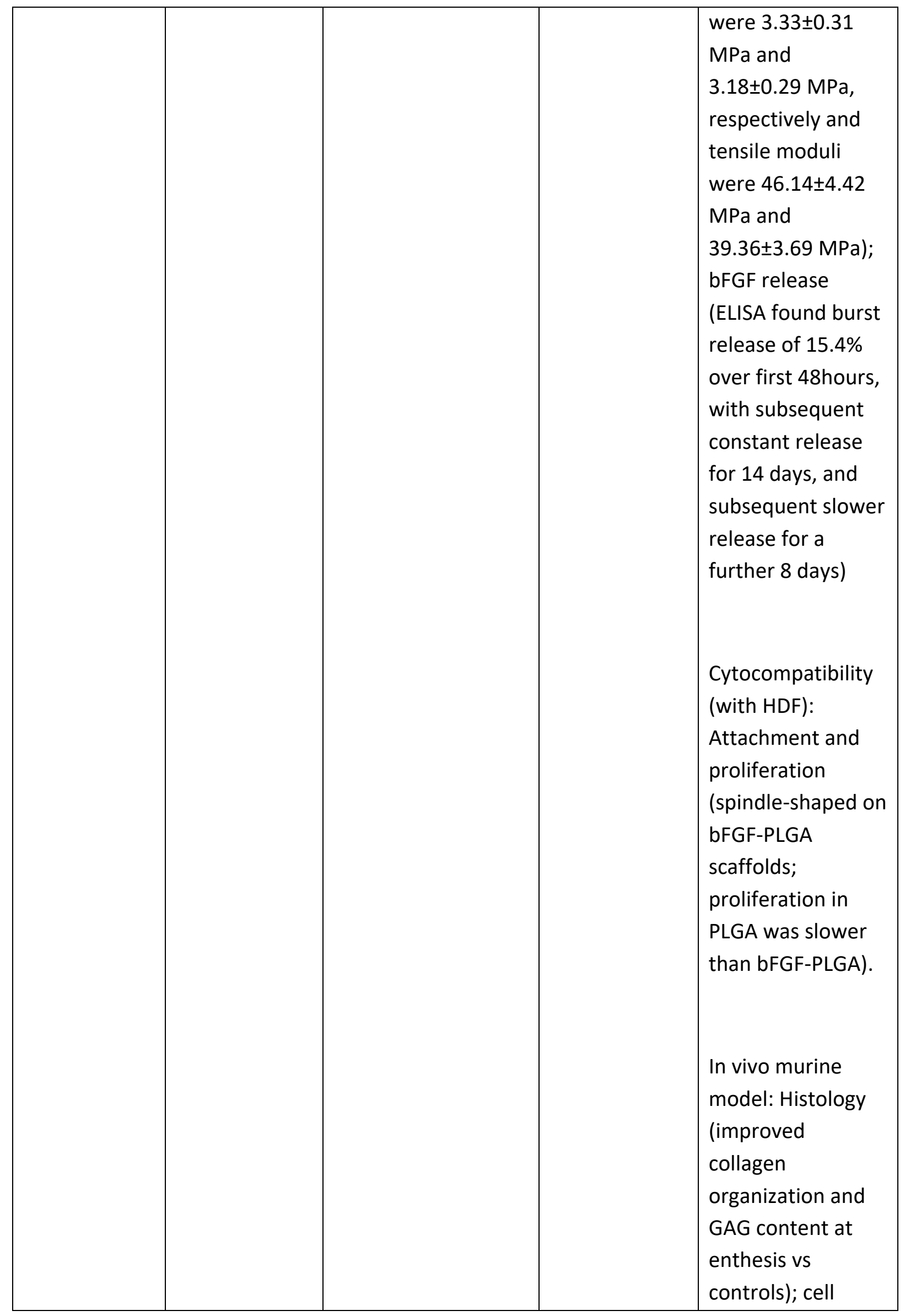




\begin{tabular}{|c|c|c|c|c|}
\hline & & & & $\begin{array}{l}\text { microscopy } \\
\text { (increased } \\
\text { fibrocartilaginous } \\
\text { organisation at } \\
\text { enthesis of bFGF- } \\
\text { PLGA scaffolds vs } \\
\text { controls); and } \\
\text { mechanical } \\
\text { properties (greater } \\
\text { ultimate load-to- } \\
\text { failure and } \\
\text { stiffness of } \\
\text { supraspinatus } \\
\text { tendon-bone } \\
\text { construct repair } \\
\text { bFGF-PLGA group } \\
\text { vs controls). }\end{array}$ \\
\hline $\begin{array}{l}\text { Yang C et al. } \\
(2014)\end{array}$ & $\begin{array}{l}\text { Silk } \\
\text { fibroin/P(LLA- } \\
\mathrm{CL} \text { ) aligned } \\
\text { nanoyarn- } \\
\text { reinforced } \\
\text { nanofibrous } \\
\text { scaffolds } \\
\text { (NRS) }\end{array}$ & $\begin{array}{l}\text { Degummed silk } \\
\text { dissolved in a } \\
\text { ternary } \\
\mathrm{CaCl}_{2} / \mathrm{H}_{2} \mathrm{O} / \mathrm{EtOH} \\
\text { solvent system, was } \\
\text { dialysed against } \\
\text { distilled water. This } \\
\text { solution was } \\
\text { blended with Poly(I- } \\
\text { lactide-co- } \\
\text { caprolactone) } \\
\text { (P(LLA-CL)) and } \\
\text { dissolved in HFIP }\end{array}$ & $\begin{array}{l}\text { Procedure } \\
\text { detail: } \\
\text { Electrospun } \\
\text { fibers were } \\
\text { collected } \\
\text { between two } \\
\text { rotating } \\
\text { collectors (1) a } \\
\text { hollow metal } \\
\text { funnel } \\
\text { attached to a } \\
\text { metal tube } \\
\text { rotating at } \\
\text { 500rpm and } \\
\text { (2) a metal } \\
\text { mandrel upon } \\
\text { a linear guide } \\
\text { slider which } \\
\text { moved back } \\
\text { and forth. }\end{array}$ & $\begin{array}{l}\text { Aligned nanoyarn- } \\
\text { reinforced } \\
\text { nanofibrous } \\
\text { scaffolds (NRS) } \\
\text { had an average } \\
\text { thickness of } \\
600 \mu \mathrm{m} \text {. } \\
\\
\text { Scaffold } \\
\text { morphology: NRS } \\
\text { had greater } \\
\text { porosity vs } \\
\text { controls. (random } \\
\text { and aligned } \\
\text { nanofibrous } \\
\text { scaffolds). More } \\
\text { consistent fibre } \\
\text { alignment and } \\
\text { greater nanofiber } \\
\text { diameters in the } \\
\text { NRS group over }\end{array}$ \\
\hline
\end{tabular}




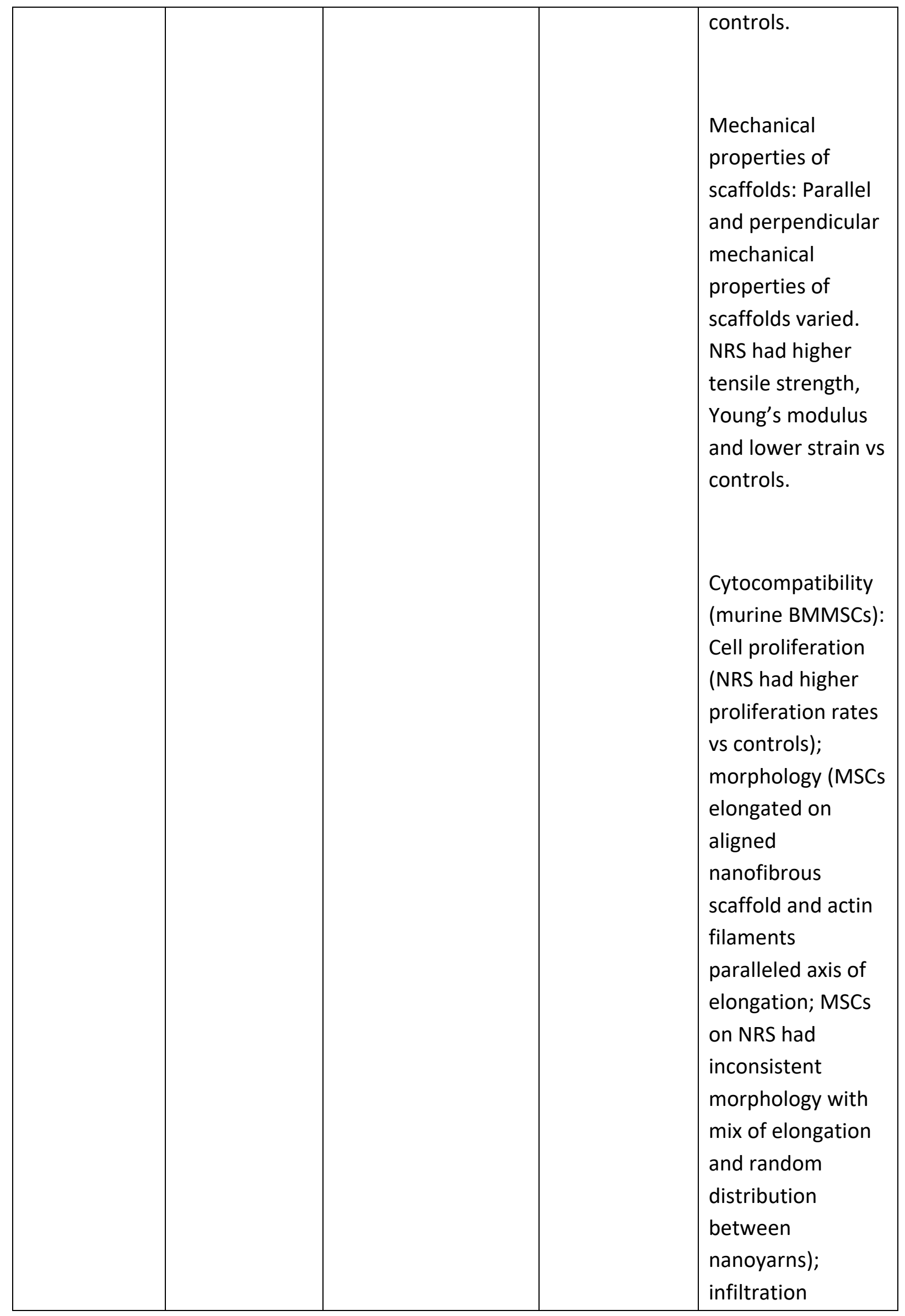




\begin{tabular}{|c|c|c|c|c|}
\hline & & & & $\begin{array}{l}\text { (infiltration to } 500 \\
\mu \mathrm{m} \text { from surface } \\
\text { of NRS vs } 40 \mu \mathrm{m} \text { in } \\
\text { random } \\
\text { nanofibrous } \\
\text { scaffolds and none } \\
\text { in aligned } \\
\text { nanofibrous } \\
\text { scaffolds during } \\
\text { the entire culture } \\
\text { period). }\end{array}$ \\
\hline $\begin{array}{l}\text { Naghashzarga } \\
\text { rE } \\
\text { et al. (2015) }\end{array}$ & $\begin{array}{l}\text { Biodegradable } \\
\text { hybrid } \\
\text { P3HB/PCL } \\
\text { nanofibers on } \\
\text { a twisted SF }\end{array}$ & $\begin{array}{l}\mathrm{PCL} \text { and } \mathrm{P} 3 \mathrm{HB} \text { were } \\
\text { separately dissolved } \\
\text { in DMF and } \\
\text { chloroform to } \\
\text { produce two } \\
\text { solvents }\end{array}$ & $\begin{array}{l}\text { Procedure } \\
\text { detail: PCL or } \\
\text { P3HB were } \\
\text { electrospun } \\
\text { on surfaces of } \\
\text { SF yarns }\end{array}$ & $\begin{array}{l}\text { Cytocompatibility } \\
\text { (with murine } \\
\text { fibroblasts): No } \\
\text { change in cell } \\
\text { viability. } \\
\text { Tensile modulus: } \\
\text { PCL-SF had the } \\
\text { greatest tensile } \\
\text { load, by coating } \\
\text { the SF yarns with } \\
\text { electrospun } \\
\text { nanofibers, the } \\
\text { mechanical } \\
\text { properties can be } \\
\text { made more similar } \\
\text { to those of native. }\end{array}$ \\
\hline $\begin{array}{l}\text { Jiang S et al. } \\
\text { (2015) }\end{array}$ & $\begin{array}{l}\text { Drug delivery } \\
\text { (celecoxib) }\end{array}$ & $\begin{array}{l}\text { PELA and celecoxib } \\
\text { were dissolved in } \\
\text { DCM and DMF }\end{array}$ & $\begin{array}{l}\text { Procedure } \\
\text { detail: } \\
\text { Electrospinnin } \\
\text { g needle was } \\
\text { fitted with a } \\
\text { 'round wire } \\
\text { mesh focusing } \\
\text { cage' }\end{array}$ & $\begin{array}{l}\text { Drug release: } \\
\text { Increasing } \\
\text { [Celecoxib] was } \\
\text { correlated to } \\
\text { increasing burst } \\
\text { release during the } \\
\text { first } 48 \text { hours. A } \\
\text { sustained release } \\
\text { followed for } 8 \\
\text { days. }\end{array}$ \\
\hline
\end{tabular}




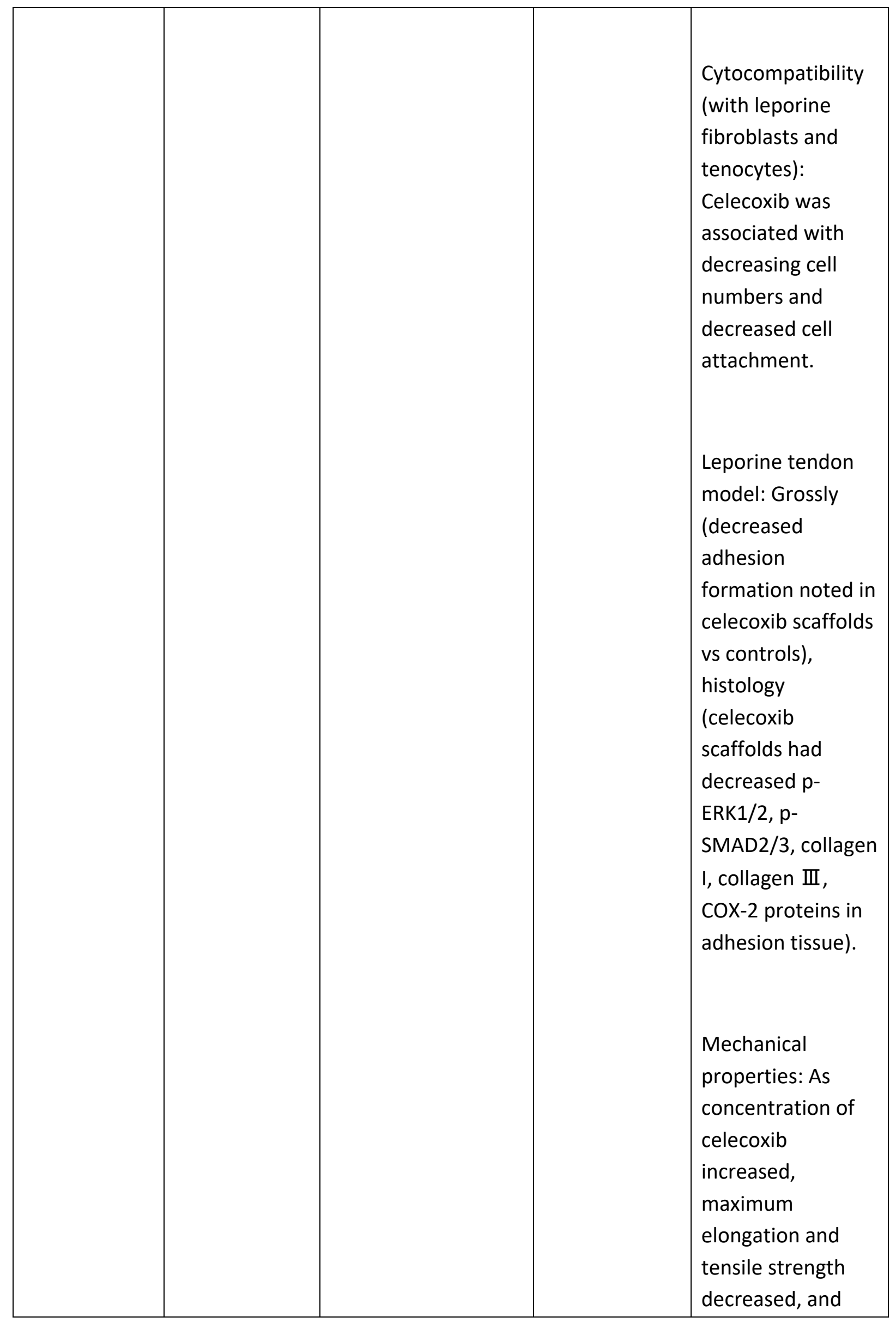




\begin{tabular}{|c|c|c|c|c|}
\hline & & & & $\begin{array}{l}\text { maximum elastic } \\
\text { modulus } \\
\text { increased. }\end{array}$ \\
\hline $\begin{array}{l}\text { He X et al. } \\
(2014)\end{array}$ & $\begin{array}{l}\text { Addition of } \\
\text { nanoparticles } \\
\text { to influence } \\
\text { mechanical } \\
\text { properties }\end{array}$ & $\begin{array}{l}\text { Purified cotton } \\
\text { (medical grade) was } \\
\text { processed into both } \\
\text { CNCs and a cellulose } \\
\text { solution, combined } \\
\text { and electrospun }\end{array}$ & $\begin{array}{l}\text { Standard } \\
\text { electrospinnin } \\
\text { g technique to } \\
\text { a rotating } \\
\text { collector at } \\
\text { different } \\
\text { RPMs to } \\
\text { manipulate } \\
\text { fibre } \\
\text { alignment }\end{array}$ & $\begin{array}{l}\text { Mechanical } \\
\text { properties - CNCs } \\
\text { at } 20 \% \mathrm{w} / \mathrm{v} \\
\text { increased tensile } \\
\text { strength when } \\
\text { tested in the same } \\
\text { direction of fibre } \\
\text { alignment from } \\
16.6 \mathrm{MPa} \text { to } \\
33.6 \mathrm{MPA} \text { (101.7\%) } \\
\text { and elastic } \\
\text { modulus from } \\
0.69 \mathrm{GPa} \text { to } \\
\text { 1.87GPA (171.6\%). } \\
\text { Cytotoxicity-MTT } \\
\text { testing assay } \\
\text { revealed CNCs had } \\
\text { no negative effects } \\
\text { on cell viability } \\
\text { and proliferation } \\
\text { compared to pure } \\
\text { cellulose nanofibre } \\
\text { scaffolds }\end{array}$ \\
\hline $\begin{array}{l}\text { Kolluru PV et } \\
\text { al. (2013) }\end{array}$ & $\begin{array}{l}\text { Post } \\
\text { fabrication } \\
\text { coating of } \\
\text { electrospun } \\
\text { fibres with } \\
\text { mineral } \\
\text { component }\end{array}$ & $\begin{array}{l}\text { PLGA (MW 50- } \\
75 \mathrm{~kg} / \mathrm{mol}, 85: 15 \\
\text { lactide/glycolide) } \\
\text { dissolved to } 25 \% \\
\text { w/v in } 80 / 20 \\
\text { DCM/DMF }\end{array}$ & $\begin{array}{l}\text { Standard } \\
\text { electrospinnin } \\
\text { g technique } \\
\text { with scaffolds } \\
\text { submerged in } \\
\text { Simulated } \\
\text { Body Fluid } \\
\text { (SBF) } \\
\text { containing } 10 \\
\text { times more } \\
\text { calcium and }\end{array}$ & $\begin{array}{l}\text { Mechanical - PLGA } \\
\text { fibres } \\
\text { demonstrated } \\
\text { uniform circular } \\
\text { cross sections, } \\
\text { non-uniform cross } \\
\text { sections and } \\
\text { uniform ellipsoidal } \\
\text { cross section } \\
\text { morphologies. The } \\
\text { mechanical }\end{array}$ \\
\hline
\end{tabular}




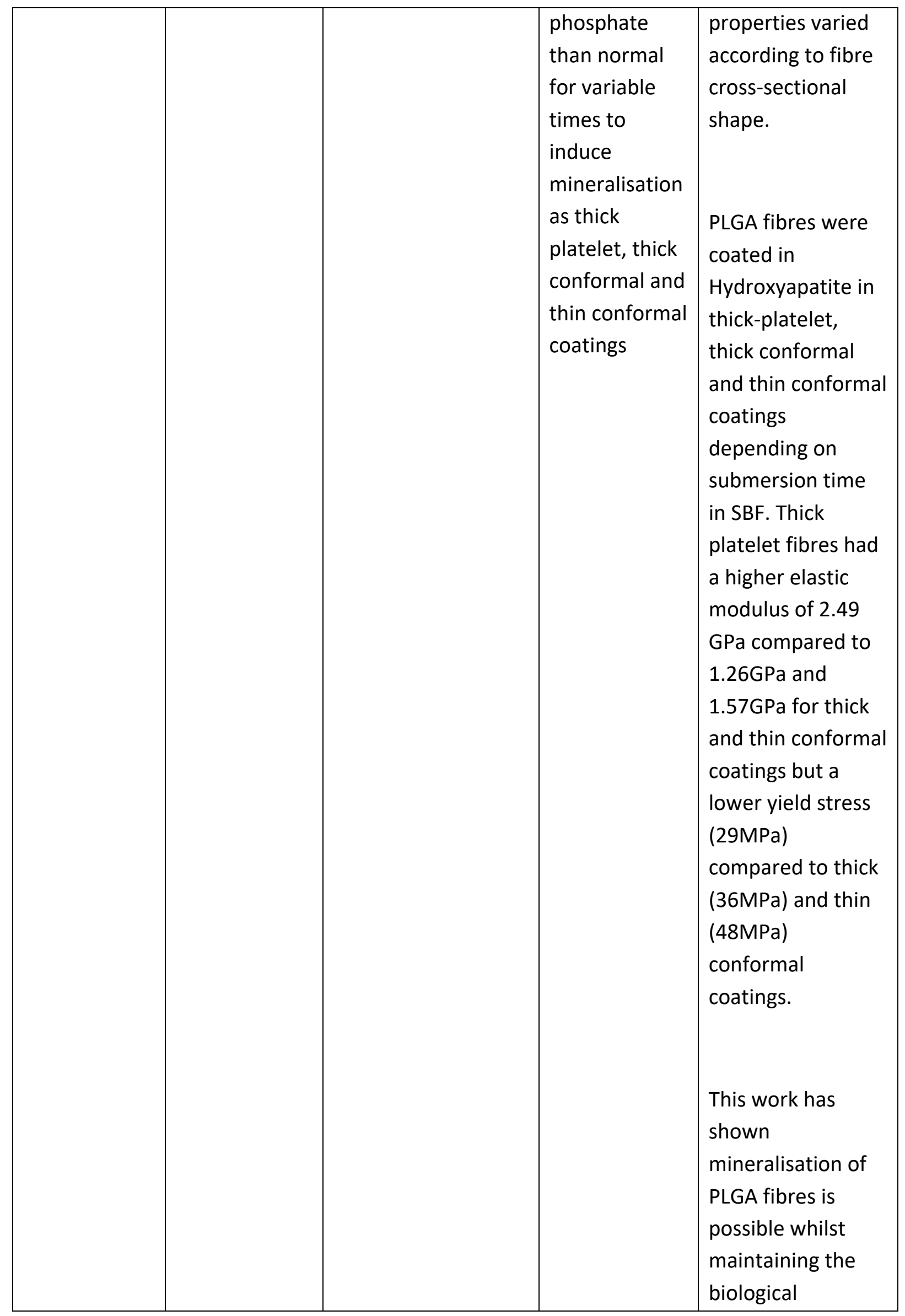




\begin{tabular}{|c|c|c|c|c|}
\hline & & & & $\begin{array}{l}\text { functionality of } \\
\text { underlying PLGA } \\
\text { fibres as a } \\
\text { biomaterial. }\end{array}$ \\
\hline $\begin{array}{l}\text { Chainani A et } \\
\text { al. (2013) }\end{array}$ & $\begin{array}{l}\text { Multilayered } \\
\text { scaffolds } \\
\text { coated post- } \\
\text { fabrication } \\
\text { with tendon } \\
\text { derived ECM } \\
\text { (TDM), } \\
\text { fibronectin } \\
\text { (FN) or } \\
\text { phosphate- } \\
\text { buffered } \\
\text { saline (PBS) }\end{array}$ & $\begin{array}{l}\text { Fresh porcine } \\
\text { tendons, minced, } \\
\text { lyophilized and } \\
\text { pulverized into a } \\
\text { powder. } \\
\text { Human fibronectin }\end{array}$ & $\begin{array}{l}\text { PCL spun } \\
\text { through } \\
\text { conventional } \\
\text { electrospinnin } \\
\text { g techniques } \\
\text { onto a saline } \\
\text { bath. } \\
\text { Coatings } \\
\text { achieved } \\
\text { through direct } \\
\text { pipetting of } \\
\text { solutions on } \\
\text { to scaffolds } \\
\text { and allowing } \\
\text { to dry prior to } \\
\text { UV } \\
\text { sterilisation } \\
\text { and use. } \\
\text { hASCs seeded } \\
\text { and cultured } \\
\text { for up to } 28 \\
\text { days }\end{array}$ & $\begin{array}{l}\text { Mechanical } \\
\text { properties - } \\
\text { different coatings } \\
\text { and culture times } \\
\text { had no effect on } \\
\text { the Young's } \\
\text { modulus. Yield } \\
\text { strain increased } \\
\text { from day } 0 \text { to day } \\
28 \text { when seeded } \\
\text { with hASCs. Yield } \\
\text { stress also } \\
\text { increased } \\
\text { significantly over } \\
28 \text { days culture for } \\
\text { FN coated } \\
\text { scaffolds. } \\
\text { tendon } \\
\text { differentiation) } \\
\text { tenascin-C } \\
\text { (markers of } \\
\text { scaffolds. Collagen } \\
\text { coating. Collagen } \\
\text { increased, most } \\
\text { greatly on TDM } \\
\text { dsDNA and } \\
\text { sulphated } \\
\text { glycosaminoglycan } \\
\text { levels increased } \\
\text { over time } \\
\text { independent of } \\
\text { colar - } \\
\text { cont also } \\
\text { ted and }\end{array}$ \\
\hline
\end{tabular}




\begin{tabular}{|c|c|c|c|c|}
\hline & & & & $\begin{array}{l}\text { increased over } \\
\text { time independent } \\
\text { of scaffold coating. } \\
\text { Immunoflouresenc } \\
\text { e demonstrated } \\
\text { greater collagen } 1 \\
\text { deposition } \\
\text { through the full } \\
\text { thickness of TDM } \\
\text { scaffolds. } \\
\text { Cellular - } \\
\text { Histology showed } \\
\text { infiltration } \\
\text { through the entire } \\
\text { thickness of all } \\
\text { scaffolds. }\end{array}$ \\
\hline $\begin{array}{l}\text { Xu et al. } \\
(2013)\end{array}$ & $\begin{array}{l}\text { Nanoyarn } \\
\text { scaffold with } \\
\text { increased } \\
\text { porosity for } \\
\text { cell infiltration } \\
\text { and } \\
\text { nutrient/wast } \\
\text { e exchange }\end{array}$ & $\begin{array}{l}\text { Poly(I-lacride-co-e- } \\
\text { caprolactone) } \\
(\mathrm{P}(\mathrm{LLA}-\mathrm{CL}) \text { (MW } \\
=300,000) \\
\text { Collagen } \\
\text { Primary rabbit } \\
\text { tenocytes }\end{array}$ & $\begin{array}{l}8 \% \text { w/v 90:10 } \\
\text { P(LLA-CL)- } \\
\text { collagen } \\
\text { solutions were } \\
\text { electrospun } \\
\text { using a } \\
\text { modified } \\
\text { dynamic liquid } \\
\text { supporting } \\
\text { system. Fibres } \\
\text { are spun into } \\
\text { water } \\
\text { circulating } \\
\text { around a } \\
\text { vortex prior to } \\
\text { collecting on a } \\
\text { rotating } \\
\text { mandrel. }\end{array}$ & $\begin{array}{l}\text { Morphological - } \\
\text { Random, aligned } \\
\text { and nanoyarn } \\
\text { scaffolds had fibre } \\
\text { diameters of } \\
632 \mathrm{~nm}, 643 \mathrm{~nm} \\
\text { and 641nm } \\
\text { respectively. These } \\
\text { aggregated in the } \\
\text { nanoyarn to yarn } \\
\text { diameters of } \\
9.51 \text { um. The pore } \\
\text { size of the } \\
\text { nanoyarn } \\
\text { ( } 28.5 \text { um) was } \\
\text { much greater than } \\
\text { the random } \\
\text { (4.31um) and } \\
\text { aligned (4.43um) } \\
\text { scaffolds. The } \\
\text { porosity of the } \\
\text { random and }\end{array}$ \\
\hline
\end{tabular}




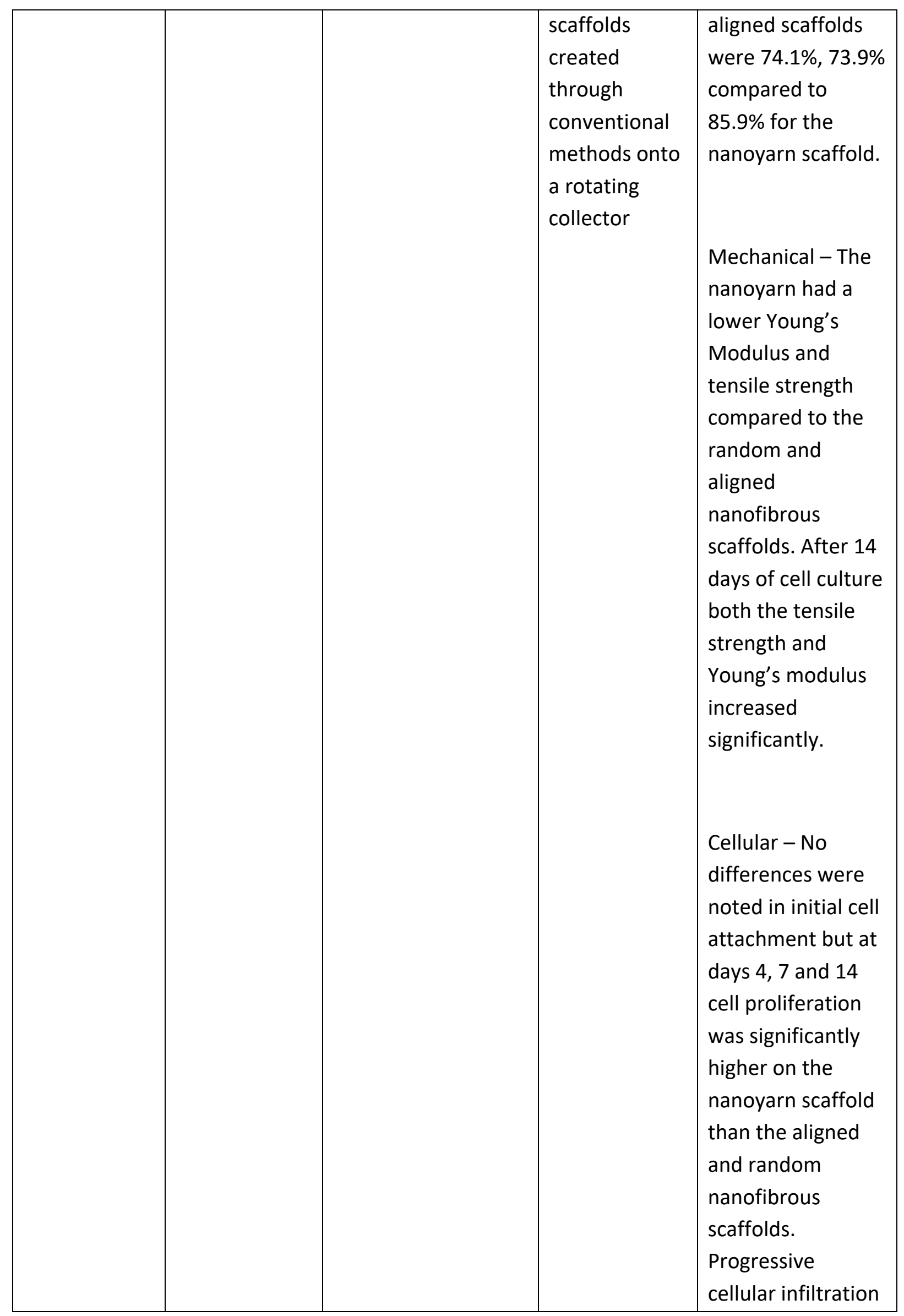




\begin{tabular}{|c|c|c|c|c|}
\hline & & & & $\begin{array}{l}\text { into the nanoyarn } \\
\text { scaffold was } \\
\text { observed in } \\
\text { contrast to the } \\
\text { non-yarn scaffolds. } \\
\text { Molecular- } \\
\text { Nanoyarn } \\
\text { scaffolds had } \\
\text { higher rtPCR } \\
\text { expression of } \\
\text { Collagen } 1 \text {, } \\
\text { tenascin-C, } \\
\text { biglycan and } \\
\text { decorin compared } \\
\text { to random } \\
\text { nanofibrous } \\
\text { scaffolds after } 7 \\
\text { days of culture. } \\
\text { These were not } \\
\text { significantly } \\
\text { different to } \\
\text { aligned scaffolds. } \\
\text { However by } 14 \\
\text { days in culture, } \\
\text { these genes were } \\
\text { expressed at } \\
\text { significantly higher } \\
\text { levels compared to } \\
\text { both aligned and } \\
\text { random } \\
\text { nanofibrous } \\
\text { scaffolds. } \\
\text { to }\end{array}$ \\
\hline $\begin{array}{l}\text { Liu S et al. } \\
(2013)\end{array}$ & $\begin{array}{l}\text { bFGF loaded } \\
\text { nanoparticles } \\
\text { electrospun to } \\
\text { promote } \\
\text { sustained }\end{array}$ & $\begin{array}{l}\text { Poly-I-lactic acid } \\
\text { (PLLA), MW =50,000 } \\
\text { Dextran }(\mathrm{Mw}= \\
64,000-76,000)\end{array}$ & $\begin{array}{l}\text { Dextran was } \\
\text { mixed with } \\
\text { bFGF, freeze } \\
\text { dried and } \\
\text { processed to } \\
\text { create fine }\end{array}$ & $\begin{array}{l}\text { Morphological - } \\
\text { DGNs were } \\
\text { observed } \\
\text { distributed } \\
\text { throughout } \\
\text { electrospun fibres }\end{array}$ \\
\hline
\end{tabular}




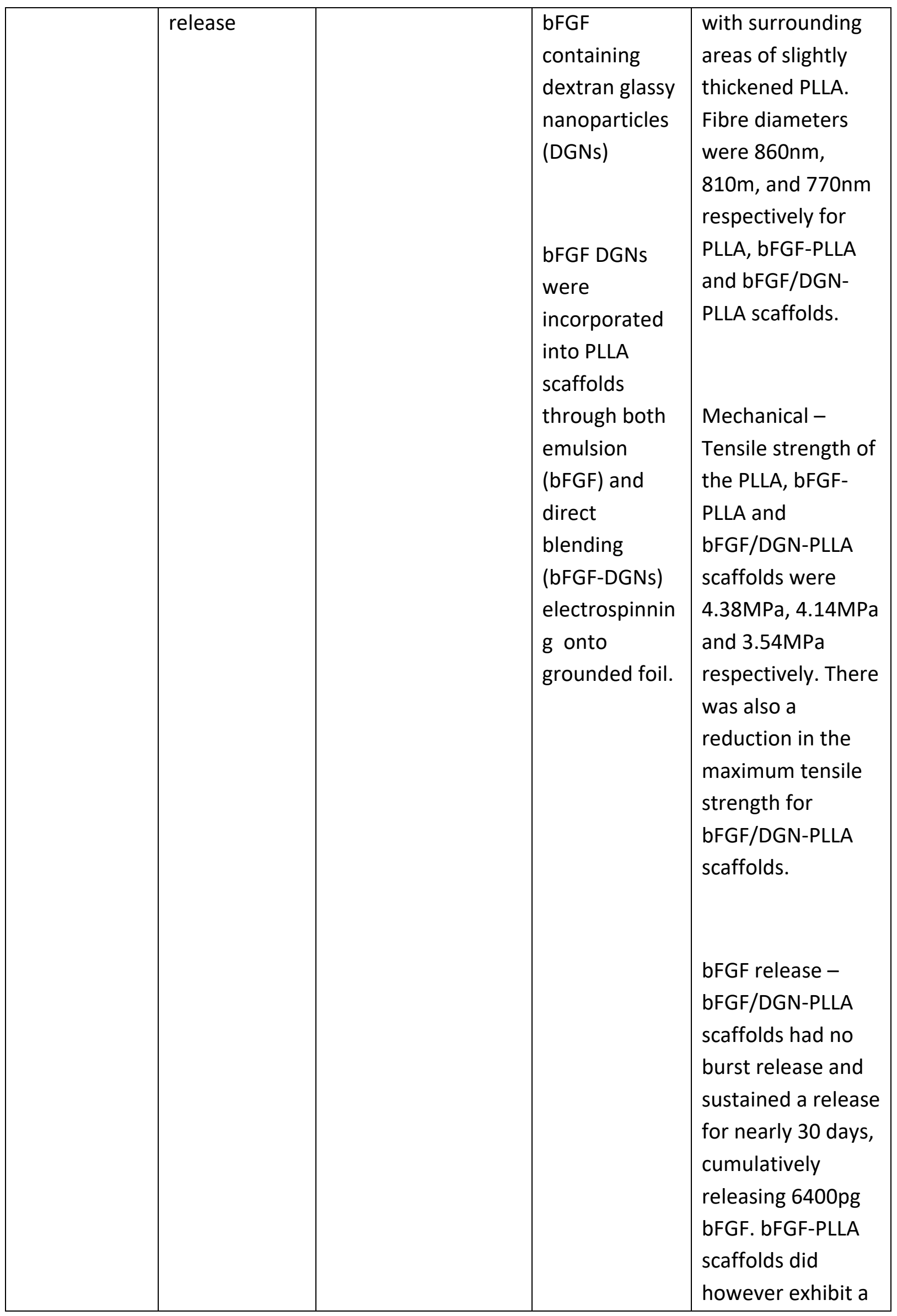




\begin{tabular}{|c|c|c|c|c|}
\hline & & & & $\begin{array}{l}\text { burst release, only } \\
\text { had a } 20 \text { day } \\
\text { release profile } \\
\text { with a cumulative } \\
\text { release of only } \\
2900 . \\
\text { Cellular - In vitro - } \\
\text { after } 1 \text { and } 4 \text { days } \\
\text { culture, fibroblast } \\
\text { number was } \\
\text { significantly } \\
\text { greater on } \\
\text { bFGF/DGN-PLLA } \\
\text { scaffolds } \\
\text { compared to } \\
\text { bFGF-PLLA and } \\
\text { PLLA scaffolds. }\end{array}$ \\
\hline $\begin{array}{l}\text { Liu et al. } \\
\text { (2012) }\end{array}$ & $\begin{array}{l}\text { Bilayer } \\
\text { hyaluronic- } \\
\text { PCL fibrous } \\
\text { inner layer } \\
\text { and PCL } \\
\text { fibrous outer } \\
\text { layer to } \\
\text { represent } \\
\text { tendon sheath } \\
\text { and reduce } \\
\text { adhesion } \\
\text { formation }\end{array}$ & $\begin{array}{l}\text { PCL (MW = 50,000) } \\
\text { Hyaluronic acid }\end{array}$ & $\begin{array}{l}\mathrm{PCL} / \mathrm{HA} \\
\text { blended } \\
\text { solutions of } \\
\text { various ratios } \\
\text { were prepared } \\
(0 \%, 4 \%, 8 \% \\
\text { an } 12 \%) . \\
\mathrm{PCL} \text { and } \\
\mathrm{PCL} / \mathrm{HA} \\
\text { solutions were } \\
\text { electrospun } \\
\text { sequentially }\end{array}$ & $\begin{array}{l}\text { Morphological - } \\
\text { outer layer PCL } \\
\text { fibres had } \\
\text { diameters of } \\
\text { 3.66um. Inner } \\
\text { layers of } 12 \%, 8 \% \text {, } \\
4 \% \text { and } 0 \% \text { HA had } \\
\text { diameters of } \\
2.86 \text { um, } 2.99 \text { um, } \\
3.42 \text { um and } \\
3.89 \text { um } \\
\text { respectively. }\end{array}$ \\
\hline
\end{tabular}




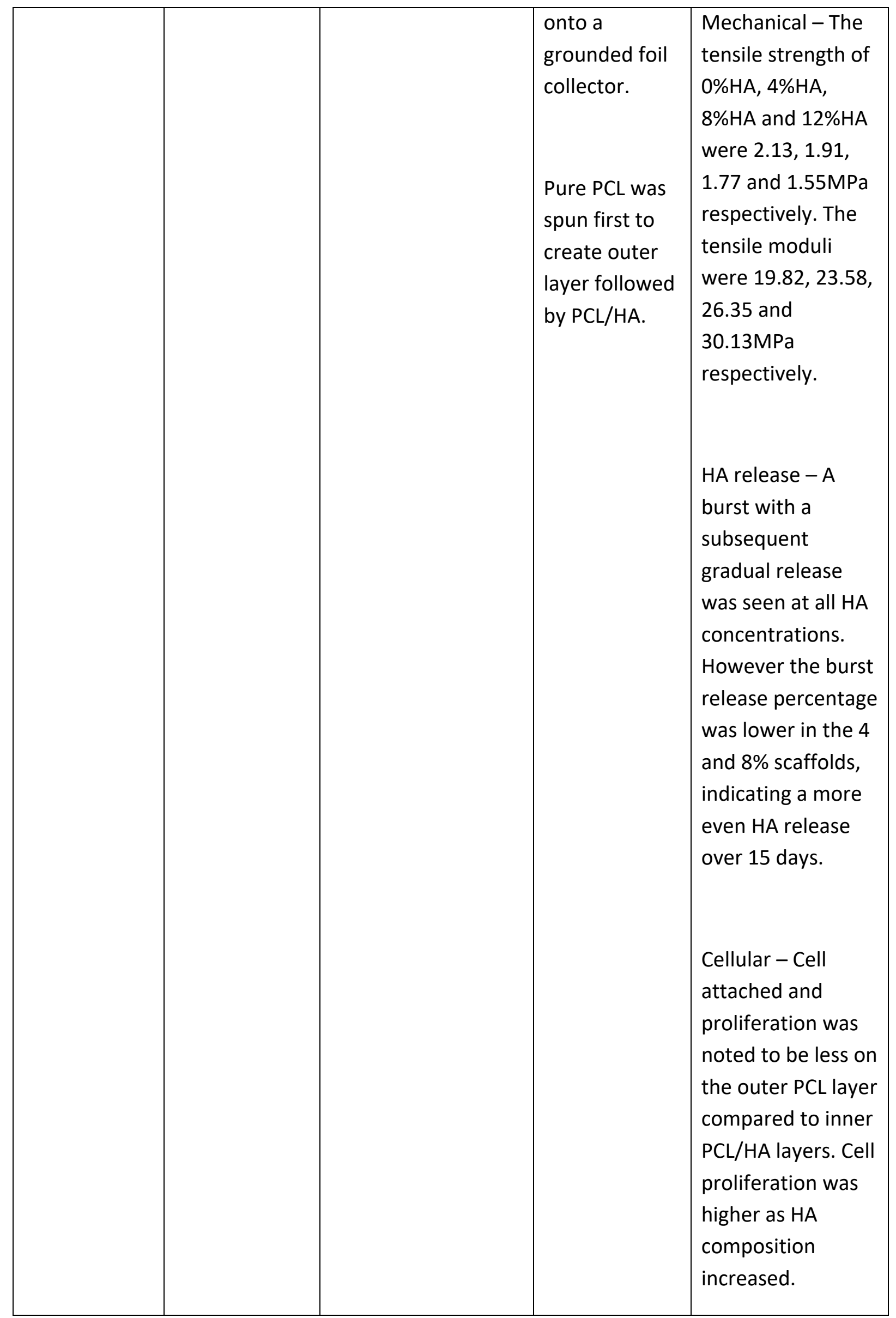




\begin{tabular}{|c|c|c|c|c|}
\hline & & & & $\begin{array}{l}\text { Animal models } \\
\text { (chicken) - use of } \\
\text { the biomimetic } \\
\text { PCL/12\%HA layer } \\
\text { significantly } \\
\text { reduced the } \\
\text { severity of } \\
\text { peritendinous } \\
\text { adhesions and } \\
\text { increased tendon } \\
\text { healing scores in a } \\
\text { chicken model } \\
\text { compared to } \\
\text { controls with no } \\
\text { scaffold or with } \\
\text { plain PCL scaffolds. }\end{array}$ \\
\hline $\begin{array}{l}\text { Ni et al. } \\
(2012)\end{array}$ & $\begin{array}{l}\text { Photochemica } \\
\text { I Tissue } \\
\text { Bonding (PTB) } \\
\text { of an ES silk } \\
\text { scaffold to } \\
\text { provide } \\
\text { mechanical } \\
\text { support and } \\
\text { reduce } \\
\text { adhesion } \\
\text { formation }\end{array}$ & $\begin{array}{l}\text { Silk from Bobyx Mori } \\
\text { silkworm cocoons }\end{array}$ & $\begin{array}{l}\text { Electrospinnin } \\
\text { g was } \\
\text { conducted on } \\
\text { a parallel plate } \\
\text { circuit. } \\
\text { 3 different } \\
\text { methods were } \\
\text { used to repair } \\
\text { a rabbit } \\
\text { Achilles } \\
\text { tendon injury; } \\
\text { a suture repair } \\
\text { (SR), an PTB } \\
\text { electrospun } \\
\text { repair } \\
\text { (ES/PTB) and a } \\
\text { group } \\
\text { combining } \\
\text { both as a SR + } \\
\text { ES/PTB repair. }\end{array}$ & $\begin{array}{l}\text { Animal model } \\
\text { (rabbit) - The use } \\
\text { of an ES/PTB layer } \\
\text { considerably } \\
\text { reduced adhesions } \\
\text { at day } 7 \text {, day } 14 \\
\text { and day } 28 \\
\text { compared to the } \\
\text { SR group. The use } \\
\text { of ES/PTB alone } \\
\text { did not provide } \\
\text { sufficient } \\
\text { mechanical } \\
\text { support but the } \\
\text { combination of a } \\
\text { SR+ ES/PTB not } \\
\text { only reduced } \\
\text { adhesion but also } \\
\text { improved } \\
\text { mechanical } \\
\text { properties of the } \\
\text { healing tendon, } \\
\text { with significantly }\end{array}$ \\
\hline
\end{tabular}




\begin{tabular}{|c|c|c|c|c|}
\hline & & & & $\begin{array}{l}\text { greater Young's } \\
\text { modulus at day } 7 \\
\text { and } 14 .\end{array}$ \\
\hline $\begin{array}{l}\text { Beason et al. } \\
(2012)\end{array}$ & $\begin{array}{l}\text { Sacrificial } \\
\text { fibre } \\
\text { component } \\
\text { (PEO) to } \\
\text { increase } \\
\text { scaffold } \\
\text { porosity }\end{array}$ & $\begin{array}{l}\text { Poly(e-caprolactone) } \\
\text { (PCL) } \\
\text { Poly(ethylene Oxide) } \\
\text { (PEO) }\end{array}$ & $\begin{array}{l}\text { PCL scaffolds } \\
\text { prepared } \\
\text { through } \\
\text { standardised } \\
\text { electrospinnin } \\
\text { g techniques. } \\
\text { PCL/PEO } \\
\text { scaffolds were } \\
\text { co- } \\
\text { electrospun. } \\
\text { On } \\
\text { submersion in } \\
\text { ethanol, PEO } \\
\text { is soluble, } \\
\text { leaving behind } \\
\text { a PCL scaffold } \\
\text { with increased } \\
\text { porosity. } \\
\text { Rodent } \\
\text { supraspinatus } \\
\text { tear model } \\
\text { repaired with } \\
\text { no scaffold } \\
\text { (control), PCL } \\
\text { or the } \\
\text { PCL/PEO } \\
\text { scaffold. } \\
\text { Re }\end{array}$ & $\begin{array}{l}\text { Animal model (rat) } \\
\text { - Cells had } \\
\text { invaded and } \\
\text { colonised PCL } \\
\text { scaffolds at } 4 \text { and } \\
8 \text { weeks. This was } \\
\text { surprisingly } \\
\text { greater than the } \\
\text { PCL/PEO scaffolds } \\
\text { with an increased } \\
\text { porosity. The } \\
\text { reduction in fibre } \\
\text { diameter may } \\
\text { have allowed } \\
\text { greater } \\
\text { compression, } \\
\text { reducing space for } \\
\text { cell invasion and } \\
\text { proliferation. }\end{array}$ \\
\hline
\end{tabular}

Table 1: A summary of the review results. Acronyms:

ASCs: Adipose-derived Mesenchymal Stem Cells; BMMSCs: Bone Marrow Mesenchymal Stem Cells; CNC: Cellulose Nano-crystals; DCM: dichloromethane; DGN: dextran glassy nanoparticles; DMF: $\mathrm{N}, \mathrm{N}$ dimethylformamide; ECM: extracellular matrix; EtOH: ethanol; FN: fibronectin; HA: Hyaluronan; 
hASC: human Adipose-derived Mesenchymal Stem Cells; HDF: Human dermal fibroblasts; HFIP: 1,1,1,3,3,3-hexafluoro-2-propanol; IVD: Intervertebral disc; MMC: mitomycin-C; MWCNTs: Multiwalled-carbon-nanotubes; NPS: Naproxen Sodium; PBS: phosphate-buffered saline; PCL: Poly( $\varepsilon$ caprolactone); PEO: poly(ethylene oxide); PLGA: Poly (lactic-co-glycolic) acid; P(LLA-CL): Poly(Ilacride-co-e-caprolactone); PLLA: poly(I-lactic acid); PTB: Photochemical Tissue Bonding; SF: Silk fibroin; SR: Suture Repair; TCP: Tissue culture plastic; THF: Tetrahydrofuran; TNMD: Tenomodulin; 